\title{
Observed 20th century desert dust variability: impact on climate and biogeochemistry
}

\author{
N. M. Mahowald ${ }^{1}$, S. Kloster ${ }^{1}$, S. Engelstaedter ${ }^{1}$, J. K. Moore $^{2}$, S. Mukhopadhyay ${ }^{3}$, J. R. McConnell ${ }^{4}$, S. Albani ${ }^{1,5}$, \\ S. C. Doney ${ }^{6}$, A. Bhattacharya ${ }^{3}$, M. A. J. Curran ${ }^{7,8}$, M. G. Flanner ${ }^{9}$, F. M. Hoffman ${ }^{10}$, D. M. Lawrence ${ }^{11}$, \\ K. Lindsay ${ }^{11}$, P. A. Mayewski ${ }^{12}$, J. Neff ${ }^{13}$, D. Rothenberg ${ }^{1}$, E. Thomas ${ }^{14}$, P. E. Thornton ${ }^{9}$, and C. S. Zender ${ }^{2}$ \\ ${ }^{1}$ Department of Earth and Atmospheric Sciences, Cornell University, Ithaca NY, 14853, USA \\ ${ }^{2}$ Department of Earth System Science, University of California, Irvine, Irvine, CA, 92697, USA \\ ${ }^{3}$ Department of Earth and Planetary Sciences, Harvard University, Cambridge, MA, 02138, USA \\ ${ }^{4}$ Division of Hydrologic Sciences, Desert Research Institute, Reno, NV 89512, USA \\ ${ }^{5}$ Department of Environmental Sciences, University of Milano-Bicocca, Milano, 20126, Italy \\ ${ }^{6}$ Marine Chemistry and Geochemistry, Woods Hole Oceanographic Institution, Woods Hole, MA, 02543, USA \\ ${ }^{7}$ Australian Antarctic Division, Kingston, Tasmania, 7050, Australia \\ ${ }^{8}$ Antarctic Climate and Ecosystems Cooperative Research Centre, Hobart, Tasmania, 7001, Australia \\ ${ }^{9}$ Department of Atmospheric, Oceanic and Space Sciences, University of Michigan, Ann Arbor, MI, 48109, USA \\ ${ }^{10}$ Computational Earth Sciences Group, Oak Ridge National Laboratory, Oak Ridge, TN, 37831, USA \\ ${ }^{11}$ Climate and Global Dynamics Division, National Center for Atmospheric Research, Boulder, CO 80307, USA \\ ${ }^{12}$ Climate Change Institute, University of Maine, Orono, ME, 04469, USA \\ ${ }^{13}$ Geosciences Department and Environmental Studies Program, University of Colorado, Boulder, CO, 80301, USA \\ ${ }^{14}$ British Antarctic Survey, Cambridge, CB3 0ET, UK
}

Received: 12 April 2010 - Published in Atmos. Chem. Phys. Discuss.: 17 May 2010

Revised: 19 October 2010 - Accepted: 8 November 2010 - Published: 19 November 2010

\begin{abstract}
Desert dust perturbs climate by directly and indirectly interacting with incoming solar and outgoing long wave radiation, thereby changing precipitation and temperature, in addition to modifying ocean and land biogeochemistry. While we know that desert dust is sensitive to perturbations in climate and human land use, previous studies have been unable to determine whether humans were increasing or decreasing desert dust in the global average. Here we present observational estimates of desert dust based on paleodata proxies showing a doubling of desert dust during the 20th century over much, but not all the globe. Large uncertainties remain in estimates of desert dust variability over 20th century due to limited data. Using these observational estimates of desert dust change in combination with ocean, atmosphere and land models, we calculate the net radiative effect of these observed changes (top of atmosphere) over the 20th century to be $-0.14 \pm 0.11 \mathrm{~W} / \mathrm{m}^{2}$ (1990-1999 vs. 1905-1914). The estimated radiative change
\end{abstract}

due to dust is especially strong between the heavily loaded 1980-1989 and the less heavily loaded 1955-1964 time periods $\left(-0.57 \pm 0.46 \mathrm{~W} / \mathrm{m}^{2}\right)$, which model simulations suggest may have reduced the rate of temperature increase between these time periods by $0.11^{\circ} \mathrm{C}$. Model simulations also indicate strong regional shifts in precipitation and temperature from desert dust changes, causing $6 \mathrm{ppm}(12 \mathrm{PgC})$ reduction in model carbon uptake by the terrestrial biosphere over the 20th century. Desert dust carries iron, an important micronutrient for ocean biogeochemistry that can modulate ocean carbon storage; here we show that dust deposition trends increase ocean productivity by an estimated $6 \%$ over the 20th century, drawing down an additional $4 \mathrm{ppm}(8 \mathrm{PgC})$ of carbon dioxide into the oceans. Thus, perturbations to desert dust over the 20th century inferred from observations are potentially important for climate and biogeochemistry, and our understanding of these changes and their impacts should continue to be refined. 


\section{Introduction}

Desert dust or mineral aerosols are soil particles suspended in the atmosphere, and are considered a "natural" aerosol constituent. There is strong evidence that desert dust is very sensitive to climate, globally changing by a factor of 3-4 between glacial and interglacial time periods (Kohfeld and Harrison, 2001), and by a factor of four regionally over the latter part of the 20th century (Prospero and Lamb, 2003). However, how humans are perturbing desert dust is not well known. It is unclear whether humans are increasing or decreasing the size of deserts through climate change and elevated carbon dioxide effects (Mahowald, 2007). In addition humans could be changing desert dust aerosols directly by removing surface vegetation for agriculture (Gillette et al., 1997) or pasture usage (Neff et al., 2005), or through altered water usage (Reheis, 1997). Globally, the net effect of humans on desert dust emissions remains uncertain, but could be between $-20 \%$ to $+60 \%$ (Tegen and Fung, 1995; Prospero et al., 2002; Mahowald and Luo, 2003; Tegen et al., 2004; Mahowald et al., 2004; Moullin and Chiapello, 2006; Mahowald et al., 2009).

Variability in desert dust is likely to be climatically important, as desert dust interferes with both incoming short wave and outgoing long wave radiation (Miller and Tegen, 1998). In addition, desert dust can interact with liquid clouds (Rosenfeld and Nirel, 1996) and frozen ice clouds (Sassen, 2002; DeMott et al., 2003), and thereby perturb the optical properties of clouds and change precipitation patterns (Rosenfeld et al., 2001; Mahowald and Kiehl, 2003; Hoose et al., 2008). Desert dust also contains small amounts of iron and is thought to be the dominant source of new iron to some regions of the open ocean (Fung et al., 2000). Iron is an important micronutrient in the oceans (Martin et al., 1991; Boyd and Law, 2001), and iron deposition has been linked to nitrogen fixation in the oceans (Falkowski et al., 1998). Thus changes in dust fluxes to the ocean have the potential to modify ocean biogeochemistry (e.g., Parekh et al., 2006; Moore et al., 2006; Aumont et al., 2008).

In this study, we use a set of paleodata observations for the 20th century to reconstruct the temporal evolution of desert dust for different source areas for the first time. We combine the observations with a dust emissions/atmospheric transport model to estimate global changes in dust sources, distributions and deposition over the 20th century. We then simulate the impact of these changes on climate and biogeochemistry using existing models. We also estimate the uncertainties in our approach.

\section{Methodology}

\subsection{Dust variability reconstruction over 20th century from data}

Ice, lake core and coral record data provide valuable information about the variability in dustiness in the past, and here we use the data presented in Table 1 to reconstruct desert dust distributions over the period from 1870 to 2000 . We use a combination of model provenance studies with geochemical provenance studies, when available, to estimate the dominant source deposited at each site. We divide the world into 7 different source areas (North Africa, Middle East/Central Asia, East Asia, North America, Australia, South America, South Africa), and use the observations to infer a time varying source strength for each source area. This approach assumes that the variability in deposition at the sites is dominated by variability in source strength, not transport variability; the model results support this assumption for the sites used here to constrain the source variability (see Sect. 3). The exceptions are the Greenland and high Andes sites as discussed below.

We estimate the deposition variability at every grid box:

$\mathrm{TD}(x, y, t)=\sum_{i} \mathrm{SD}_{i}(x, y) \cdot S_{i}(t) / \sum_{i} \mathrm{SD}_{i}(x, y)$

Where $\operatorname{TD}(x, y, t)$ is the relative deposition at a particular location and time period (relative to $1980-2000), \mathrm{SD}_{i}(x, y)$ is the climatologically annual average deposition at location $x, y$ for each source $(i)$, and $S_{i}(t)$ is the derived time variability for each source region $(i)$, derived in the following paragraphs. The $\mathrm{SD}_{i}(x, y)$ comes from model simulations described in (Mahowald, 2007), where one source region is turned on for each model simulation. The strength of each source, aerosol optical depth and deposition to oceans for each source is indicated in Table 2. The derivation of the time tendency of each source region $\left(S_{i}(t)\right)$ is described next.

For the Southern Hemisphere sources, we rely to a large extent on the results of a recent modeling study ( $\mathrm{Li}$ et al., 2008), since other studies are characterized by too large of an Australian source (Luo et al., 2003; Mahowald, 2007). While geochemical provenance studies can be valuable for deducing the sources for different dust deposition sites, there is limited data (Grousset and Biscaye, 2005). For the present climate, information on long-range dust provenance for Antarctica is so far limited to the central East Antarctic Plateau, the main source being Argentina (Delmonte et al., 2007), with significant contribution from a secondary source which could be either the Puna-Altiplano (Delmonte et al., 2008; Gaiero, 2008) or Australia (Marino et al., 2008). For the Antarctic cores, we chose our sources to be consistent with these model and observational studies (Table 3). Some paleorecords (e.g. West Antarctic Ice Sheet and Siple, Table 1) are associated with two different sources, and so 
Table 1. The location of the paleodata sites and associated source used to infer the 20th century dust trends.

\begin{tabular}{|c|c|c|c|c|c|}
\hline Paleodata site & $\begin{array}{l}\text { Type } \\
\text { of data }\end{array}$ & $\begin{array}{l}\text { Latitude } \\
\left({ }^{\circ} \mathrm{N}\right)\end{array}$ & $\begin{array}{r}\text { Longitude } \\
\left({ }^{\circ} \mathrm{E}\right)\end{array}$ & $\begin{array}{l}\text { Associated } \\
\text { Source }\end{array}$ & Citation \\
\hline West Antarctic Ice Sheet & Ice core & -79.5 & 247.5 & Australia/South America & (J. McConnell, personal communication, 2009) \\
\hline Newall Glacier & Ice core & -77 & 162 & Australia & (Mayewski and al., 1995) \\
\hline Siple & Ice core & -76 & 276 & S. America/Australia & (Mosley-Thompson et al., 1990) \\
\hline Gomez & Ice core & -73.9 & 289.7 & S. America & (J. McConnell, personal communication, 2009) \\
\hline Law Dome & Ice core & -65.6 & 112.5 & Australia & $\begin{array}{l}\text { (Souney et al., 2002) } \\
\text { (J. McConnell, personal communication, 2009) }\end{array}$ \\
\hline James Ross Island & Ice core & -64 & 302 & S. America & (McConnell et al., 2007) \\
\hline Cape Verde & Coral core & 16 & 336 & N. Africa & (Mukhopadhyay and Kreycik, 2008) \\
\hline Dasuopu & Ice core & 28 & 85 & Middle East/Central Asia & (Thompson et al., 2000) \\
\hline Red Sea & Coral core & 29.5 & 35 & Middle East/Central Asia & (S. Mukhopadhyay, personal communication, 2009) \\
\hline San Juan Mountain Lakes & Lake core & 38 & 252 & N. America & (Neff et al., 2008) \\
\hline Everest & Ice core & 28 & 86.9 & Middle East/Central Asia & (Kaspari et al., 2007) \\
\hline
\end{tabular}

Table 2. Source Apportionment: the relative strength of the different sources in the source apportionment simulations. The values represent the total contribution of the source area to the globally averaged aerosol optical depth and deposition to oceans.

\begin{tabular}{lccc}
\hline $\begin{array}{l}\text { Source } \\
\text { area }\end{array}$ & $\begin{array}{c}\text { Source } \\
\text { Strength (Tg/year) }\end{array}$ & $\begin{array}{c}\text { Aerosol } \\
\text { optical depth }\end{array}$ & $\begin{array}{c}\text { Deposition to } \\
\text { oceans (Tg/year) }\end{array}$ \\
\hline North Africa & 1367 & 0.0146 & 276 \\
Middle East/Central Asia & 760 & 0.0067 & 97.6 \\
Australia & 120.3 & 0.0010 & 25 \\
North America & 121.9 & 0.00098 & 35 \\
East Asia & 100.6 & 0.00062 & 7.7 \\
South America & 98.5 & 0.00086 & 31 \\
South Africa & 6.25 & 0.00016 & 4.8 \\
\hline
\end{tabular}

influence both source areas in their time series, but at half the weight of the other records.

We do not include several cores because we do not think their variability over the last 100 years represents dustiness over a large region that can be associated with a particular source. For GISP (Donarummo et al., 2002) and Penny (Zdanowicz et al., 1998), the variability over the 20th century appears to be governed by transport and deposition to the ice cores (Meeker and Mayewski, 2002), not necessarily broad scale source or dustiness changes. Several tropical cores (Quelccaya, Thompson et al., 1984; Huascaran, Thompson et al., 1995; and Kilamanjaro, Thompson et al., 2002) are far downwind from the dust source areas, and at high elevations, and seem to represent the variability in dustiness in remote regions (Mahowald et al., 2010), while here we want to characterize the source changes for regions dominating large parts of the globe. We have no paleodata to constrain the South African or East Asian sources, so we let them remain constant over the time period considered here.

The dust data we use are from downwind of the source regions, which means that we are deriving the long range transported dust variability from different source regions. This is also the fraction that will impact climate and biogeochem- istry the most because it is the fraction transported away from the source regions. We recognize that the assumptions made here will impact the results of our study and that more data will determine whether these assumptions are valid or not. We evaluate the uncertainties in our approach in Sect. 4.

Once we assign each paleorecord to be representative of a source region, we average the relative dust deposition time series for the paleodust records within one source region, to produce one time series of variation for each source region $(S(i))$.

\section{Paleodata description}

We include here mostly published data (Table 1), of which we do not include a detailed description. Ice core data from Antarctica and the Tibetan plateau are used (J. McConnell, personal communication, 2009; Mayewski and al., 1995; Mosley-Thompson et al., 1990; Souney et al., 2002; McConnell et al., 2007; Kaspari et al., 2007). Lake sediment data from the San Juan Mountains in Colorado (Neff et al., 2008), and coral data from Cape Verde and the Red Sea are used (Mukhopadhyay and Kreycik, 2008; S. Mukhopadhyay, personal communication, 2009). There is one data set that 
Table 3. The location of the paleodata sites and associated source used to infer the 20th century dust trends for the Antarctic cores. The source provenance from different model studies is also given.

\begin{tabular}{|c|c|c|c|c|c|c|c|c|}
\hline Site & $\begin{array}{l}\text { Lat. } \\
\left({ }^{\circ} \mathrm{N}\right)\end{array}$ & $\begin{array}{l}\text { Long. } \\
\left({ }^{\circ} \mathrm{E}\right)\end{array}$ & $\begin{array}{l}\text { MATCH } \\
\text { (Luo et } \\
\text { al., 2003) }\end{array}$ & $\begin{array}{l}\text { MASINGAR } \\
\text { (Tanaka and } \\
\text { Chiba, 2006) }\end{array}$ & $\begin{array}{l}\text { CAM } \\
\text { (Mahowald, } \\
2007 \text { ) }\end{array}$ & $\begin{array}{l}\text { GFDL } \\
\text { (Li et } \\
\text { al., 2008) }\end{array}$ & $\begin{array}{l}\text { Associated Source } \\
\text { Assumed } \\
\text { here }\end{array}$ & Citation \\
\hline West Antarctic Ice Sheet & -79.5 & 247.5 & AUS & AUS & AUS & AUS/SAM & Australia/South America & $\begin{array}{l}\text { (J. McConnell, personal } \\
\text { communication, 2009) }\end{array}$ \\
\hline Newall Glacier & -77 & 162 & AUS & AUS & AUS & AUS & Australia & $\begin{array}{l}\text { (Mayewski et } \\
\text { al., 1995) }\end{array}$ \\
\hline Siple & -76 & 276 & AUS & AUS & AUS & S. Am. & S. America/Australia & $\begin{array}{l}\text { (Mosley-Thompson } \\
\text { et al., 1990) }\end{array}$ \\
\hline Gomez & -73.9 & 289.7 & AUS & AUS & AUS & S. Am. & S. America & $\begin{array}{l}\text { (J. McConnell, personal } \\
\text { communcation, 2009) }\end{array}$ \\
\hline Law Dome & -65.6 & 112.5 & AUS & AUS & S. Am. & Aus./S. Am. & Australia & $\begin{array}{l}\text { (J. McConnell, personal } \\
\text { communication 2009; } \\
\text { Souney et al., 2002) }\end{array}$ \\
\hline James Ross Island & -64 & 302 & AUS & AUS & AUS & S. Am. & S. America & $\begin{array}{l}\text { (McConnell } \\
\text { et al., 2007) }\end{array}$ \\
\hline
\end{tabular}

we extrapolate prior to the 1950s (Cape Verde used for North Africa), and several unpublished datasets. We describe these in more detail here.

The North African source is responsible for about half of the atmospheric loading (Luo et al., 2003). For this source, we only have data from a coral record at Cape Verde going back to the 1950s (Mukhopadhyay and Kreycik, 2008). This dust deposition data correlates well with both in situ concentration data observed at Barbados (Prospero and Lamb, 2003) and negative precipitation anomalies over the Sahel region of North Africa (Mukhopadhyay and Kreycik, 2008). In order to extend the North African record back in time, we use gridded observed temperature and precipitation data, which has been converted to a Palmer Drought Severity Index (Dai et al., 2004). There is a statistically significant correlation $(r=-0.66, p<0.0001)$ between the Palmer drought severity index for the Sahel region and the Cape Verde coral record for the 1955-2000 time period. This relationship is slightly stronger than that seen between precipitation in the Sahel and the coral record $(r=-0.60, p<0.0001)$. Using the slope between the PDSI and Cape Verde dust deposition record and the observational-based estimates for the Palmer Drought Severity Index going back to 1905 , we extrapolate the dustiness of the North African source back to 1905 (Fig. 1). We could do the same analysis but based on the shorter in situ Barbados concentration data (1968 to 2000) (Prospero and Lamb, 2003), and extrapolate a similar less dusty early part of the 20th century (Fig. 1). Using the Cape Verde dataset to extend back to 1905 estimates less change in North Africa than the Barbados data would (Fig. 1).

In recent years, the correlation between precipitation and Barbados dust is not as robust as the precipitation is recovering, but the dust is staying high (Mahowald et al., 2009). This is consistent with land use change contributing to the variability at Barbados (Mahowald et al., 2002), or other unknown processes contributing to dust variability. If land use were contributing to the dust variability at Barbados, it would imply a larger change in dust in North Africa than estimated here (Fig. 1). A new observationally-based study suggests a large increase in dust coming from North Africa during the 20th century, which they attribute to land use in North Africa (Mulitza et al., 2010). This study extends over many centuries, and also shows time periods where the inferred precipitation correlates well with dust, while during other time periods, there is an increase in dust, unrelated to climate, which they interpret as a contribution to dust from land use (Mulitza et al., 2010). There are issues with the interpretation of this data, since the small size particles that they interpret as riverine inputs could also be desert dust from farther upwind, however the results of this new observationally based study support the large increase we see during the 20th century from North Africa.

Next we describe the unpublished datasets used for this study. For the datasets from Law Dome, Gomez and the West Antarctic Ice Sheet Divide deep drilling sites, we used continuous measurements of the rare earth element Cerium $(\mathrm{Ce})$ (McConnell and Edwards, 2008) in shallow ice cores to develop detailed records of continental dust concentration and flux. Ce is an ideal tracer because it derives almost entirely (>99\%) from continental dust. Annual dust concentrations were derived from 40 to $80 \mathrm{Ce}$ measurements per year in the cores using an abundance of $0.000083 \mathrm{ng}_{\mathrm{Ce}} \mathrm{g}_{\text {dust }}^{-1}$.

For the Red Sea dataset, Helium-4 $\left({ }^{4} \mathrm{He}\right)$ measurements were carried out on annual growth bands of a Porites lutea coral collected in the northern Red Sea from the Ras Mohammad National park at the southern tip of Sinai Peninsula $\left(27^{\circ} 43^{\prime} \mathrm{N}, 34^{\circ} 07^{\prime} \mathrm{E}\right)$. Previous studies have established ${ }^{4} \mathrm{He}$ to be an effective proxy for mineral dust in deep-sea 


\section{Estimated relative dustiness}

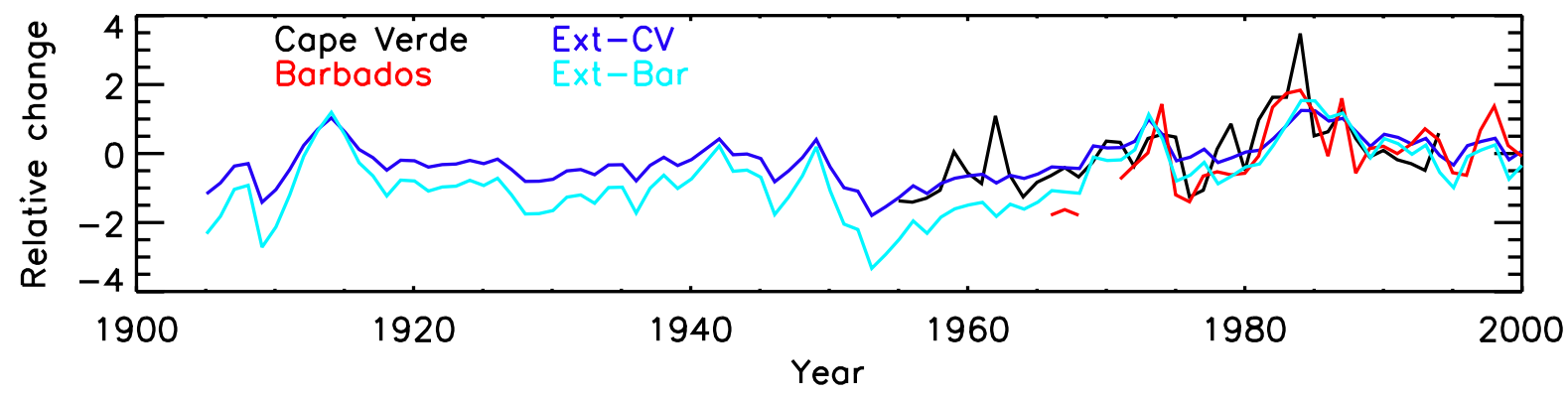

Fig. 1. Estimated relative dustiness for North Africa and North Atlantic. Cape Verde relative dustiness is shown in Black, while the extrapolated change in North African dustiness (using the Palmer Drought Severity Index-PDSI) is shown in dark blue. In situ concentration data from Barbados is shown in red (Prospero and Lamb, 2003), while extrapolated dustiness from the Barbados record and the PDSI is shown in light blue.

sediments and corals (Mukhopadhyay and Kreycik, 2008; Patterson et al., 1999; Winckler et al., 2005). The ${ }^{4} \mathrm{He}$ record therefore, provides a near-annual proxy record of dust deposition in the Northern Red Sea during the 20th century. Large fluctuations are observed in the depositional dust flux as measured in the Red Sea Porites coral. In general, dust fluxes in the first half of the 20th century are low compared to dust fluxes in the 2nd half of the 20th century, with the lowest dust fluxes occurring during the 1950's. Dust fluxes increase during the late 1960's with pronounced peaks in the 1970 's and early 1980's.

\subsection{Model descriptions}

The models used to estimate the impact of the changes in desert dust are components of the Community Climate System Model (Collins et al., 2006a). There are three sets of model simulations conducted: those with the dust model (a combined atmosphere/land model), the ocean model and the land model. We drive each of these model separately, instead of in a coupled mode, so that we can better understand the individual responses from different model components.

\subsubsection{Dust model}

For dust modeling, we use the Community Atmosphere Model/Community Land Model (Collins et al., 2006b) (CAM/CLM3.1), which includes sources, transport and deposition of desert dust; dust simulations have been compared to available observations (Mahowald et al., 2006a). The dust module used here was described previously (Zender et al., 2003a; Mahowald et al., 2006a). The model assumes that dust is generated over unvegetated, dry soils, with strong winds in regions where soil is easily erodible (Zender et al., 2003a). The easily erodible soils, or preferential source areas (Ginoux et al., 2001), are assumed here to be in regions where infrequent rains supply new sediment for entrainment into the atmosphere (Zender et al., 2003b). One small change to the simulations from previous simulations is that the veg- etation threshold is changed so that the leaf area index (LAI: surface area of leaves over surface area of land) is averaged over all vegetation types within a grid box, and if the vegetation is below $0.3 \mathrm{LAI}$, the source strength grows linearly. Previously the vegetation threshold was at $0.1 \mathrm{LAI}$ and calculated for each plant functional type. Since the vegetation types are assumed to overlap, the new approach is more consistent with the way vegetation is considered in the model.

The dust model simulations include increasing greenhouse gases and time varying anthropogenic aerosols over the historical time period (1870-2000), using the same historical forcing as Flanner et al. (2009). The model simulations are conducted using a slab ocean model, and are simulated at $\mathrm{T} 42$ (roughly $2.8^{\circ} \times 2.8^{\circ}$ resolution).

By default the dust model allows changes in soil dryness and winds to vary the strength of the source with time. Because the model includes fixed monthly average satellite derived vegetation (Bonan et al., 2002), the impact of changes in vegetation on dust source area is not included in this version of the model (Dynamic vegetation versions of this model simulate surface albedo poorly (Sealy et al., 2010), so that the dynamic vegetation version of the model was not used). Simulations conducted over the 130 year historical time period with no tuning of the dust sources were unable to capture the observed variability in deposition (shown in Sect. 3.1). This is despite the fact that the model captures observed mean global surface temperature changes (as shown in the Sect. 3).

Normally in this model, the entrainment of the dust into the atmosphere $(E(x, y, t)$ is a function of soil moisture $(\mathrm{SM})$, leaf area index (LAI), snow cover (SNOW), friction velocity (FV), and soil erodibility (SE) (see Zender et al., 2003a for a more detailed description). All but the last variable are time and spatially varying variables used or derived in the land model. The last variable (soil erodibility) is a spatially constant variable indicating the relative effectiveness of each grid box for causing dust generation (Zender et al., 2003b). 


$$
\begin{aligned}
& E(x, y, y)=\text { function }(\operatorname{SM}(x, y, t), \operatorname{LAI}(x, y, t), \\
& \operatorname{SNOW}(x, y, t), \operatorname{FV}(x, y, t), \operatorname{SE}(x, y))
\end{aligned}
$$

In order to force our model to reproduce the observed changes in deposition we add in a term proportional to our deposition changes at each gridbox (derived above from the paleodata):

$$
E_{\text {new }}(x, y, t)=\mathrm{TD}(x, y, t) \cdot E(x, y, t)
$$

This means we use our estimated deposition variability as a measure of source strength variability, a reasonable assumption since deposition in source regions is dominated by the local source and one that allows us to make one map of time evolution at each point. On top of this, the model is still allowed to vary the source strength with stronger winds or drier soils. We had planned to iterate to get the correct deposition variability, but the deposition matched the observations within the large uncertainty, so no iteration was conducted (as shown in results Sect. 3).

We calculate the climate impact of the direct forcing of dust using the CAM/CLM3.1, with a simple slab ocean model, which should include most of the effects of the ocean response to warming without the expense of a fully coupled ocean model. However, there will be errors associated with our simplification of the ocean, especially with regards to decadal time scale forcing of climate from oceans. Since we use these simulations to interpret the difference between simulations with and without dust, which is a smaller forcing than anthropogenic forcing, these biases are unlikely to be large. We conduct four ensemble members for the control case with no dust direct radiative forcing, and three ensemble members with dust direct radiative forcing. All the model cases are forced with increasing greenhouse gas concentrations in the atmosphere, changes in sulfate, black carbon and organic carbon aerosols, and volcanoes, similar to previous studies (Flanner et al., 2009).

The climate impacts of desert dust on direct radiative forcing have been shown to reproduce the few available radiative forcing estimated based on observations (Yoshioka et al., 2007; Flanner and Zender, 2006; Flanner et al., 2007). Dust in the atmosphere absorbs and scatters both long and short wave radiation, and in the global net, tends to cool the atmosphere in the dust model (Yoshioka et al., 2007). The model simulation is similar to Yoshioka et al. (2007), but small changes to the dust optical properties were made to better match observations (Flanner et al., 2009). Snow albedo reduction from dust is treated in a similar manner as black carbon, but with appropriate global-mean dust optical properties (Flanner et al., 2007). The impact of including dust in this model has been compared to observations and analyzed previously, although we did not have information about the time series of variability in the 20th century (Mahowald et al., 2006b; Yoshioka et al., 2007). The response to dust in the atmosphere is a function of both the single scattering albedo of dust (e.g. Perlwitz et al., 2001) and the surface albedo of the underlying surface (Bonfils et al., 2001; Sealy et al., 2010). For our dust model simulations we are careful to match available aerosol optical properties and radiative forcing observations as closely as possible (see Yoshioka et al., 2007).

\subsubsection{Biogeochemistry models}

The CCSM incorporates an ocean biogeochemistry module with three types of phytoplankton, zooplankton grazers, and major nutrient and iron cycling (Moore et al., 2006). This model has been compared against available observations (e.g. Doney et al., 2009). The simulations are run in the ocean-only mode (Krishnamurty et al., 2009), and are spun up with the new preindustrial dust levels, estimated here from observations at 1870-1890. The historical simulations (1870-2000) are integrated with a repeated annual cycle of atmospheric physics and are forced with dust deposition computed from the monthly mean dust fluxes from Luo et al. (2003) combined with the variability derived from Eq. (1) for each grid point and year. Two simulations are conducted, one with constant dust and constant solubility, and one with increasing dust (estimated here) and increasing solubility of iron due to air pollution (Mahowald et al., 2009). Results of the impact on ocean biogeochemistry from increases in the solubility of iron have previously been published (Krishnamurty et al., 2009). For the ocean biogeochemistry experiments, we ignore the physical forcing of aerosols for this study, and focus on the biogeochemistry of iron addition, because it is thought that is an important mechanism (e.g. Martin et al., 1991).

The land biogeochemistry response is computed using the prototype version of the Community Land Model (CLM4) that incorporates several updates relative to CLM3.5 (Oleson et al., 2008) including a land biogeochemistry model (Thornton et al., 2007; Thornton et al., 2009). The biogeochemistry model includes $\mathrm{N}$-colimitation, which will reduce the carbon uptake under higher $\mathrm{CO}_{2}$ conditions (Thornton et al., 2007), and a 2-leaf model for plant photosynthesis, which allows for the inclusion of direct versus diffuse radiation effects on photosynthesis (Thornton et al., 2007). The model is relatively insensitive to climate, with a small negative feedback of climate onto the carbon cycle (Thornton et al., 2009). The model is run offline using the hourly CAM generated climate data (e.g. temperature, precipitation and insolation) based on a control and a simulation including the dust radiative forcing (from the above described simulations). The change in carbon uptake and land productivity are estimated based on the difference between simulations including dust radiative feedbacks and excluding them.

For the land biogeochemistry experiments we focus on the physical climate forcings, and ignore any biogeochemistry impacts from direct aerosol deposition. The most important 
nutrient coming in with the dust deposition for the terrestrial biosphere is thought to be phosphorus, a limiting nutrient for tropical forests (Swap et al., 1992; Vitousek, 2003). However, the phosphorus cycle changes because of increasing phosphorus deposition are likely to be important on thousand year or longer time scales, not the hundred year time scale considered here (Okin et al., 2004).

\subsection{Radiative forcing calculation}

We conduct a set of simulations to calculate the direct radiative forcing from the dust, which requires calculating the radiation twice for each time step: once with dust included and once without, the difference yielding the instantaneous change in radiative forcing. For the climate simulations, we include several ensemble members to assess the uncertainty due to variability in the simulations or interannual variability, which tends to be smaller than the uncertainty in the optical properties (e.g. Miller and Tegen, 1998).

We also calculate the radiative forcing of the indirect aerosol effect. Because of the large uncertainties in the interaction between aerosols and cloud properties (Forster et al., 2007), our model does not explicitly include indirect effects. However, we can estimate the importance of these large changes in aerosol amount on the clouds based on estimates from the last Intergovernmental Panel on Climate Change assessment report (IPCC) (Forster et al., 2007) and assuming that aerosols act as cloud condensation nuclei in proportion to their aerosol optical depth (Rosenfeld et al., 2008). Observations suggest that aerosol optical depth is a good proxy for cloud condensation nuclei, independent of their chemistry (Rosenfeld et al., 2008), because the number and size of particles is important (but not their mass). While desert dust particles are largely insoluble, they are hydrophilic (Koretsky et al., 1997), readily attracting condensing water, and thus likely to be heavily involved in cloud formation (Rosenfeld and Nirel, 1996). In addition, desert dust particles could interact with ice nuclei (Sassen, 2002). We do not have a model that includes these impacts. Therefore, to roughly estimate the indirect forcing from dust variability we: (1) divide the total aerosol indirect effect radiative forcing estimated in the last IPCC by the total change in aerosol optical depth assumed in the IPCC, and (2) multiply the result from (1) by the observed global average change in aerosol optical depth estimated here. This can only be considered a rough estimate of the indirect effect of desert dust changes on climate.

The radiative forcing of the biogeochemistry impacts of desert dust onto the land and ocean are calculated based on the changes in atmospheric $\mathrm{CO}_{2}$ estimated from the biogeochemical models (Sect. 2.2) times the radiative forcing of $\mathrm{CO}_{2}$, based on Forster et al. (2007).

\section{Results}

\subsection{Dust variability over 20th century}

Our estimates from the available paleorecords suggest significant fluctuations in desert dust source strength from the different source areas over the 20th century (Fig. 2). There are differences in the deposition variability at the different core locations that sample each source (Fig. 2), which implies significant uncertainties in our estimated trends (discussed in more detail in Sect. 4). In our methodology, the differences in deposition variability at different sites are assumed to come from variations due to transport-deposition relationships at the individual sites. These results suggest that many of the main desert dust sources were relatively less active during the early part of the 20th century (all except North America, Fig. 1a), and many increased with time, reaching a maximum in the 1980's, during the North African/Sahel drought.

The reason for these changes in dustiness is not clear. Data suggests that desert dust responds strongly to climate, either regional variability such as due to the North African drought (Prospero and Lamb, 2003) or global variability during glacial/interglacial cycles (Petit et al., 1999). While the land surface or inundated lakes are likely to be drying due to hotter temperatures and precipitation pattern shifts (Dai et al., 2004), carbon dioxide increases may make arid plants more able to deal with water stress (Smith et al., 2000). Because of these potentially offsetting effects of humans, climate model based estimates are inconclusive, suggesting that deserts may have either expanded or contracted since the late 1800's (Mahowald, 2007). Desert dust also responds locally to agriculture and pasture land use, since both remove the vegetation that protects the soil against wind erosion (Gillette, 1988; Neff et al., 2005), but the global importance of land use is not known (Tegen and Fung, 1995; Prospero et al., 2002; Tegen et al., 2004; Mahowald et al., 2004; Yoshioka et al., 2005; Moullin and Chiapello, 2006; Mahowald et al., 2009). Water use by humans could impact desert dust (Reheis, 1997), but there is no evidence of large scale impacts from water use (Mahowald et al., 2009). The results here suggest that the net effect of climate drying, carbon dioxide fertilization and land use change by humans result in an increase in desert dust over the 20th century. This model was not able to simulate this variability without the source being forced to vary with time (dotted line in Fig. 2). Note that we were unable to extrapolate our North African source farther back than 1905, so we do not estimate the desert dust amounts in the 19th century, required for a preindustrial to current climate contrast.

As discussed in the methodology section, the model was unable to capture the observed variability in dust deposition without modification to the source strength. Once the source strength is tuned using the relative deposition time series derived in Eq. (1), the model deposition at the paleorecord sites capture the variability that we derived from the 

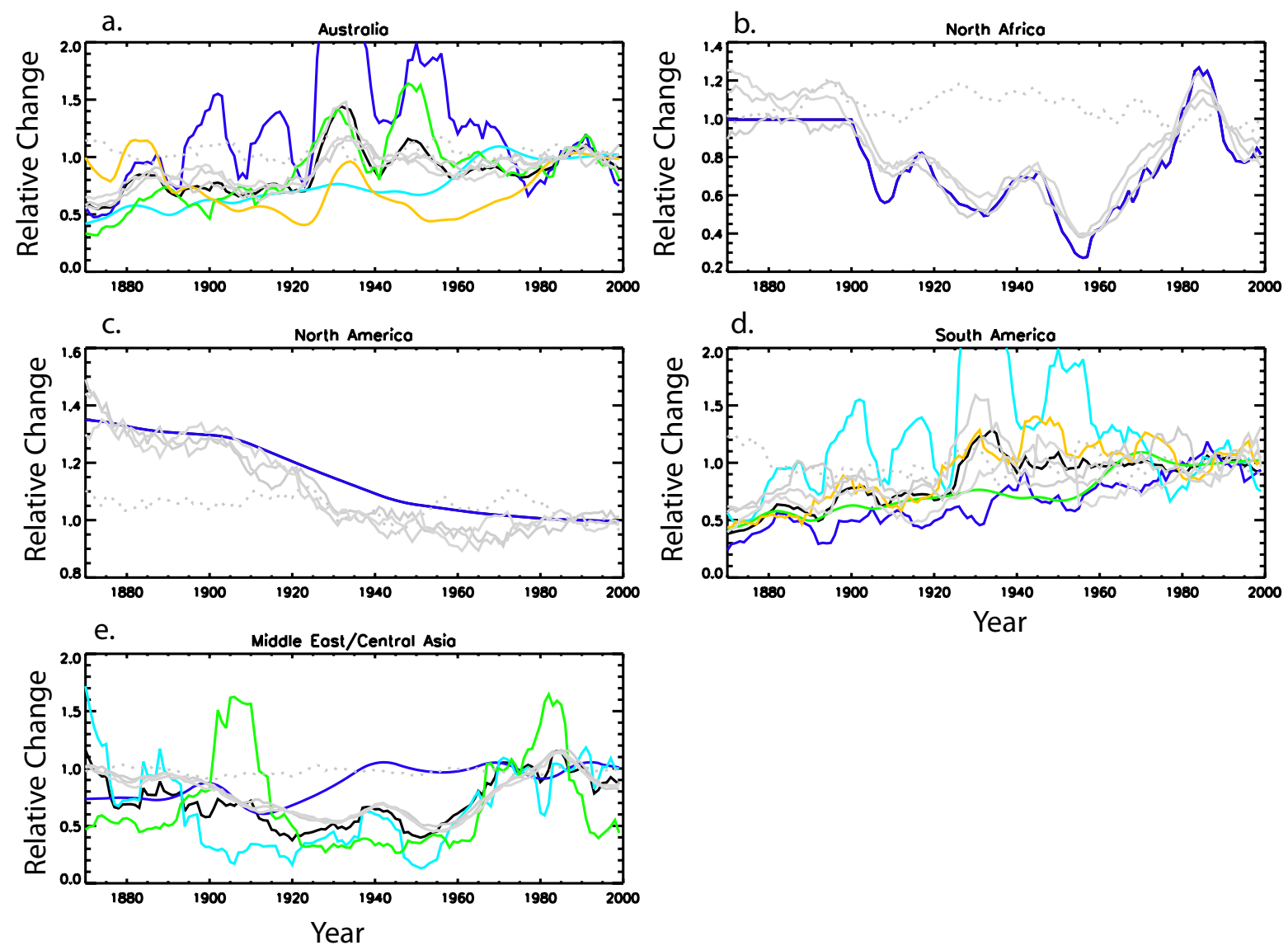

Fig. 2. Observational derived fluctuations in relative source strength and relative deposition for each paleorecord (colors) and the mean estimated source variation for each source area (black) for Australia (a), North Africa (b), N. America (c), South America (d), and Middle East/Central Asia (e). For Australia (a) the sites are WAIS (dark blue), Siple (cyan), Newall (green) and Law Dome (yellow). For North Africa (b) the site is Cape Verde (Fig. S1) (dark blue). For North America (c), the San Juan Lakes are averaged in blue. For South America (d), the sites are James Ross Island (dark blue), WAIS (cyan), Siple (green), and Gomez (yellow). For the Middle East/Central Asian source, the sites are Dasuopu (dark blue), Red Sea (cyan) and Everest (green). Also shown in grey are the ensemble model simulated dust deposition as sampled at each paleodatarecord and averaged exactly as done with the data. All values are 10-year running means.

observations (Fig. 2; grey lines compared to black lines). For this comparison, we average the model output at the same locations as the data. For this model, changes in dust transport are not important for the variability seen in the cores (at the cores we include: see Sect. 2.1 for cores not included in the data forcing the model, because transport/deposition variability is thought to be important), even though large scale changes in precipitation and temperature are simulated. This is consistent also with previous model studies (Tegen and Miller, 1998; Mahowald et al., 2003). This is even consistent with the model studies of the last glacial maximum, where to get large changes ( $>25 \%$ ) in dust deposition, changes to source areas need to be included in some models (Mahowald et al., 1999, 2006a). Some models obtain larger changes in dust source strength without changes in source area for the last glacial maximum because of stronger winds and/or dryness (Andersen et al., 1998; Werner et al., 2002). Note that
Mahowald et al. (1999) and Werner et al. (2002) use different versions of the same climate model (ECHAM).

The model estimated aerosol optical depth, a measure of the interference of the aerosols with incoming solar radiation, follows the variability in the source strength (Fig. 3b). The relative contribution of each source area to the total source, aerosol optical depth, and deposition to oceans for the source provenance studies conducted with this model show the dominance of the North African source for controlling much of the climate impact of desert dust (Table 2). The radiative forcing of the desert dust follows closely the aerosol optical depth (Fig. 3b). The average direct radiative forcing of desert dust at the top of the atmosphere over the 20th century is $-0.5 \mathrm{~W} / \mathrm{m}^{2}$, and varies strongly with time (Fig. 3b). The net change between the relatively less dusty early 20th century (1905-1914) and the dusty 1990-1999 results in a direct radiative forcing of $-0.07 \mathrm{~W} / \mathrm{m}^{2}$. The largest 
changes in radiative forcing occur between the dusty 1980's (1980-1989) and less dusty late 1950's (1955-1964), resulting in globally averaged differences in radiative forcing of $-0.28 \mathrm{~W} / \mathrm{m}^{2}$ (Fig. 4a). For reference the current net anthropogenic radiative forcing (from greenhouse gases and anthropogenic aerosols, etc.) is estimated to be $+1.6 \mathrm{~W} / \mathrm{m}^{2}$ (Forster et al., 2007), signifying that the 20th century changes in direct radiative forcing due to fluctuations in desert dust are climatically important (Fig. 4a).

As discussed in the methods, we are not able to include indirect effects of dust aerosols explicitly in this model, but instead estimate the impact of dust onto clouds. We roughly estimate the impact of changes in desert dust on the radiative budget through the indirect effect (described in Sect. 2.3), but cannot include these impacts in the atmospheric modeling study. A first order estimate of the radiative forcing from aerosol indirect effects from changing dust (Fig. 4a) is $-0.36 \mathrm{~W} / \mathrm{m}^{2}$ for $1980-1989$ vs. $1955-1964$. The indirect effect of dust changes is about the same size (and sign) as the direct effect, so that including this response doubles our estimate of the 20th century "cooling" radiative forcing of desert dust.

\subsection{Climate and biogeochemical response}

The climate impact of the dust is simulated using ensemble members including and excluding the direct radiative forcing of desert dust. The globally averaged net impact of including desert dust direct radiative forcing on model climate is a mean cooling of $-0.12{ }^{\circ} \mathrm{C}$. For comparison, when historical 20th century greenhouse gases trends and aerosols are used to force the model, the simulated temperature increase is $+0.73^{\circ} \mathrm{C}$ between the 1870 s and 1990 s (Fig. 3c). Although the mean change between the early 1900s (1905-1914) and the 1990s (1990-1999) just due to dust changes is not statistically significant, there are larger impacts for some time periods. The inclusion of desert dust changes in the model reduces the temperature rise between the relatively low dust 1955-1964 time period and the high dust 1980-1989 time period by approximately $0.11^{\circ} \mathrm{C}$; this is about $1 / 3$ of the total change between these two time periods simulated in the model (Fig. 3c), and this reduction in the rise in temperatures makes the model more consistent with the observational data (Brohan et al., 2006) (Fig. 3c). If we focus on just the land surface temperatures in the model (which the data represents better), the change in surface temperature between 1980 1990 and $1955-1965$ is 0.34 and $0.48^{\circ} \mathrm{C}$ with and without dust, respectively, while the observations show a change of $0.21^{\circ} \mathrm{C}$ (Fig. 4b); again the model including the effects of dust changes matches the data better than without the effects of dust changes. Note that after this time period, the dust is reduced and the temperature rises again. In addition, the dust cools the atmosphere over desert regions, causes subsidence locally and moves precipitation away from desert dust regions (Yoshioka et al., 2007). Because most of the desert dust is in the Northern Hemisphere, this causes a decrease in Northern Hemisphere land precipitation in the tropics between 1980-1989 compared to 1955-1964 (Fig. 4c), allowing the model to better match observational estimates of the change in precipitation (Dai et al., 2004) (Figs. 4c and 5).

Regional changes in surface temperature, precipitation and sea level pressure, as simulated in the model for the 19801989 dusty period compared to the 1955-1965 non-dusty period (Figs. 5, 6 and 7), suggest that the changes in regional climate from changes in dust are of the same order as from the changes due to other forcings (including $\mathrm{CO}_{2}$ ) for this time period, especially for the case of precipitation. For precipitation, we compare to available observations (Dai et al., 2004) and demonstrate that with dust included in the model, even without forcing the ocean, we can capture much of the large-scale shifts in precipitation between the dusty period (1980-1989) to the non-dusty period (1955-1965). This suggests that desert dust itself contributes to drought in the Sahel, for example, as argued previously (Yoshioka et al., 2007). The response of precipitation to dust is sensitive to single scattering albedo (Perlwitz et al., 2001), and our model has been carefully compared to available observations to show that it matches observed single scattering albedo (Yoshioka et al., 2007). In order to compare the model simulation to observations over oceans, we are restricted to a few datasets. Comparisons to the mean sea level pressure estimates based on observations (Allan and Ansell, 2006), suggest that including dust variability improves the comparison with increased sea level pressure over North Africa and South Atlantic, but degrades the simulation over the South Indian Ocean.

In addition to these impacts of desert dust on climate, desert dust can interact with biogeochemistry, and thereby impact atmospheric $\mathrm{CO}_{2}$ and other greenhouse gas emissions. For this study we include the impact of increasing dust solubility from air pollution (Mahowald et al., 2009) as well as changes in desert dust deposition, in a 3-dimensional model simulation of ocean biogeochemistry (Krishnamurty et al., 2009) and obtain changes in net air-sea $\mathrm{CO}_{2}$ fluxes (Fig. 3d). Changes in dust deposition result in a $6 \%$ increase in ocean productivity and a significant perturbation to the nitrogen budget, through the reduction in iron limitation of the nitrogen fixing organisms (Fig. 8). This results in an increase in the uptake of carbon dioxide by the ocean of $8 \mathrm{Pg} \mathrm{C}$ (equivalent to $4 \mathrm{ppm}$ in atmospheric $\mathrm{CO}_{2}$ ) over the 130 years of the simulation (Figs. 3 and 8). This approximately doubles the impact of human perturbations on iron deposition to the oceans simulated from changes in combustion processes only (Krishnamurty et al., 2009). Notice that for this ocean ecosystem model, anthropogenic increases in the iron deposition to the ocean are more important than anthropogenic increases in nitrogen deposition to the ocean (Krishnamurty et al., 2009). The net effect of these changes in $\mathrm{CO}_{2}$ onto the radiative balance for different time periods is shown in Fig. 4. 

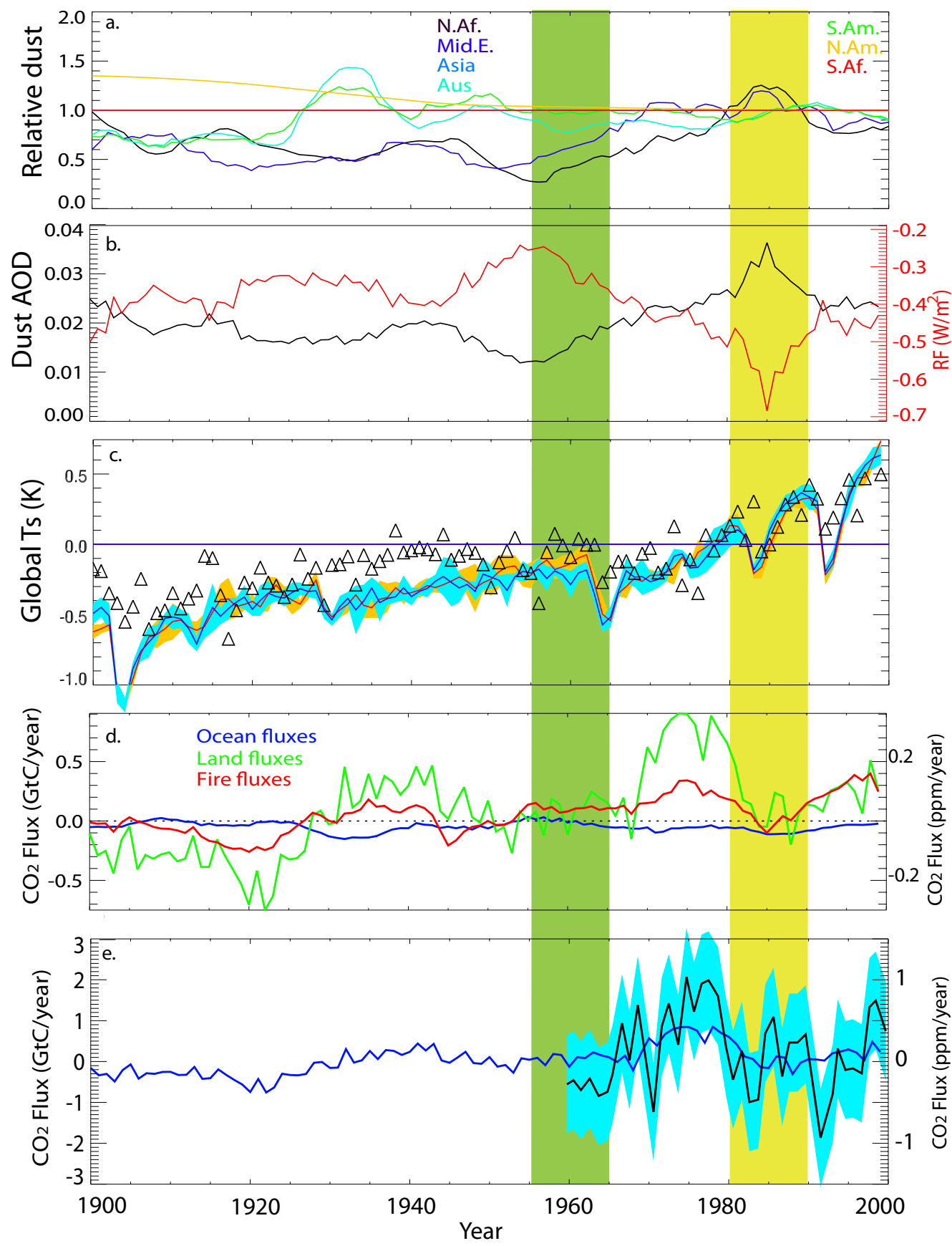

Fig. 3. The relative strength the dust source regions (normalized to 1 for each region for 1980-2000) as estimated from the observations (a) for North Africa (black), Middle East/Central Asia (dark blue), Asia (blue), Australia (cyan), South America (green), North America (yellow), and South Africa (red). The model estimated aerosol optical depth (AOD) (black) and change in instantaneous radiative forcing in $\mathrm{W} / \mathrm{m}^{2}$ (red) (b). Globally averaged surface temperature change (relative to 1960-2000) for the mean of the atmospheric general circulation model simulations without dust (blue) and with dust (red) compared against the observed changes (black triangles) (c). The variability in the ensemble simulations are shown as shaded areas for the no dust (cyan) and dust (gold) simulations. Net release of carbon dioxide in $\mathrm{GtC} /$ year deduced from the change in dust deposited to oceans (blue), land areas (green) and the fire portion of the land flux (red) (d): note that positive means a flux into the atmosphere. The net $\mathrm{CO}_{2}$ flux anomalies into the atmosphere from the land and ocean model simulations computed here including dust variability (blue line) compared to the residual $\mathrm{CO}_{2}$ flux (black) and uncertainty (cyan shading) computed from simulations not including dust variations from a recent synthesis (LeQuere et al., 2009). The shaded blue region represents the uncertainties in the residual $\mathrm{CO}_{2}$ flux (LeQuere et al., 2009). The background green and yellow boxes represent the least dusty time period (green: 1955-1964) and the most dusty time period (1980-1990) during the 20th century. 

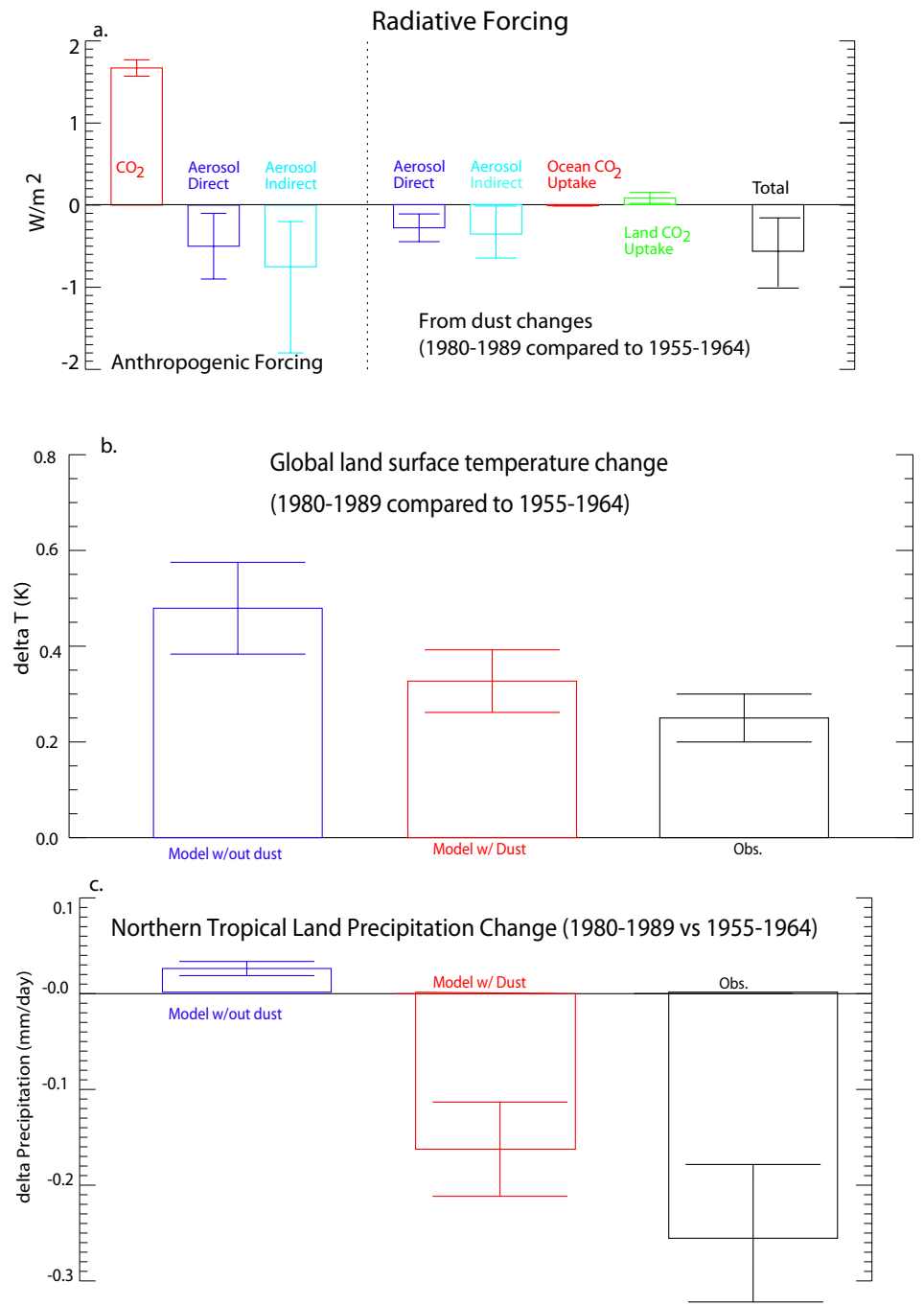

Fig. 4. Change in radiative forcing $\left(\mathrm{W} / \mathrm{m}^{2}\right)$ from changes in anthropogenic forcing (a, left panel) as estimated from the IPCC for carbon dioxide (red) (Forster, 2007), aerosol direct forcing (blue) and indirect forcing (cyan), and for (a, right panel) dust changes as estimated here for the period 1980-1989 (dusty) compared to 1955-1964 (non dusty). Dark blue indicates direct radiative forcing from dust changes, cyan indicates indirect radiative forcing from dust changes, red indicates changes in radiative forcing from ocean uptake of carbon dioxide due to changes in dust, and green indicates changes in radiative forcing from land uptake of carbon (which is opposite in sign to the other forcings). The total radiative forcing from dust changes between 1980-1989 and 1955-1964 is shown in black. The uncertainty estimates are calculated in Sect. 4. Change in globally averaged surface temperature between the dusty time period (1980-1989) compared to the non-dusty time period (1955-1964) for the model simulations (over land) without dust (blue) with dust (red) and observations (black) (Brohan et al., 2006) (b). Change in Northern Hemisphere Tropical precipitation over land $\left(0-20^{\circ} \mathrm{N}\right)$ between the dusty and non-dusty time period in the model without dust (blue), the model with dust (red) and observations (black) (Dai et al., 2004) (c). The uncertainty envelope in radiative forcing (a) comes from the uncertainty analysis in the Sect. 4, while in the uncertainty envelopes in the temperature and precipitation (b and c) represent interannual variability (and ensemble members for the model).

The 20th century changes in desert dust can impact the ability of the land biosphere to take up carbon dioxide by altering precipitation and temperature patterns (Jones et al., 2009), as well as by changing the amount and characteristics of the incoming solar radiation (Mercado et al., 2009). Using a land biogeochemistry model to simulate the impact of changing dust on the land carbon cycle, we estimate a decrease in the land uptake of carbon over the 20th century, during the transition from wetter to drier conditions due to the increase of dust (Fig. 3d). Integrated over the 20th century, this results in $6 \mathrm{ppm}(12 \mathrm{PgC})$ more $\mathrm{CO}_{2}$ in the atmosphere in the 1990's, much of it coming out through a higher incidence of fires in a climate with changing dust (Fig. 3d). The increased carbon dioxide concentrations will result in a warming (more than offsetting the ocean uptake of carbon) (Figs. 3 and 4). The net result of the land and ocean carbon 


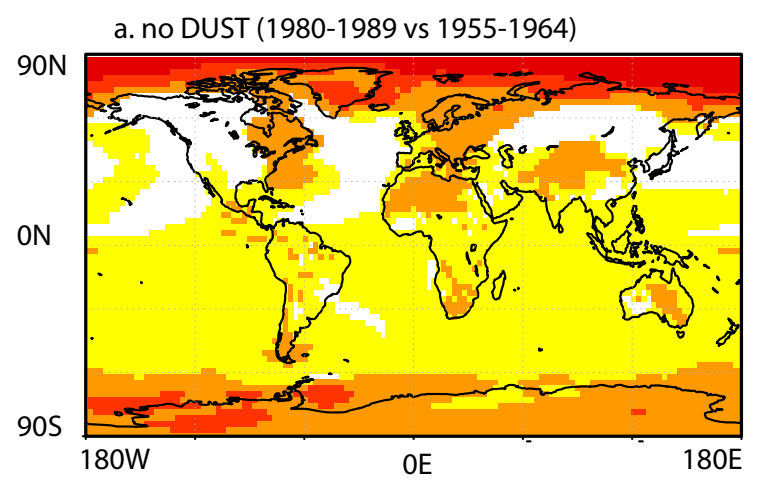

b. DUST (1980-1989 vs 1955-1964)

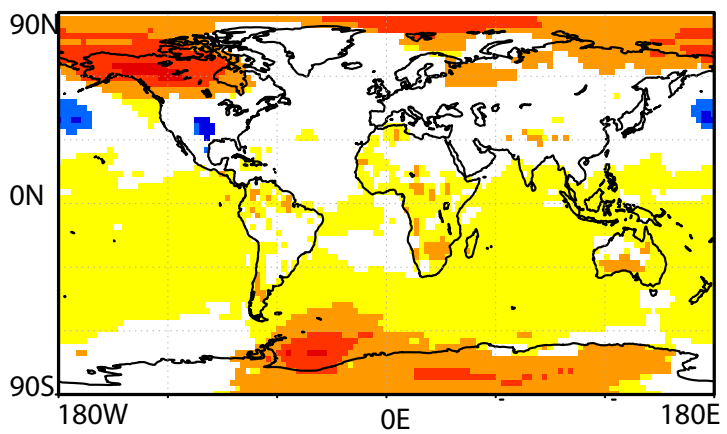

c. DUST vs. no DUST (1980-1989 vs. 1955-1964)

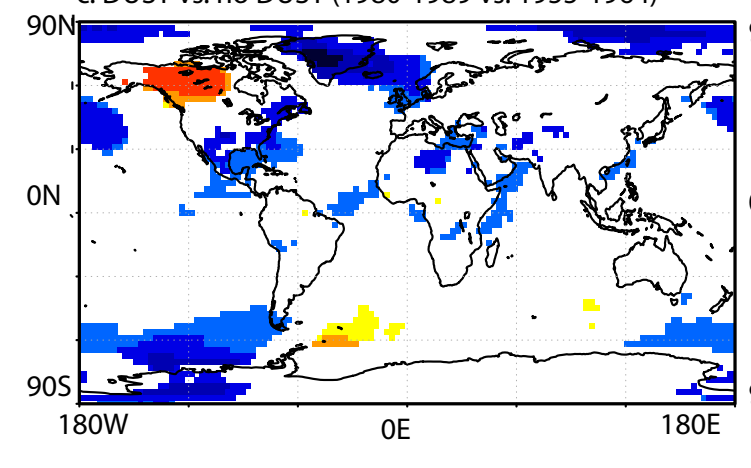

d. Obs. T (1980-1989 vs. 1955-1964)

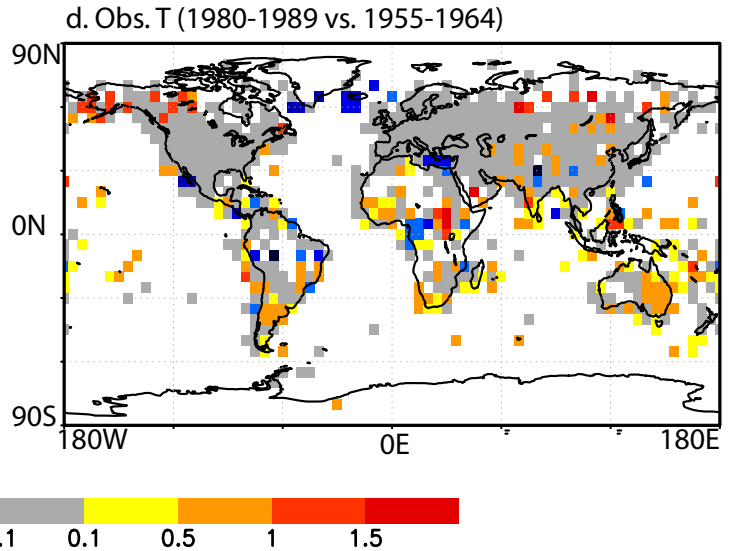

Fig. 5. Model estimated surface temperature change for 1980-1989 vs. 1955-1965 with no dust radiative forcing (a), with dust radiative forcing (b), and the difference in the surface temperature change (1980-1989 minus 1955-1965) between simulations with and without dust radiative forcing (c). The change in temperature between 1980-1989 vs. 1955-1965 from observations (only over land) (d). For (a-c) only statistically significant results at the $95 \%$ confidence level are shown, including all the ensemble members. For (d) the grey color indicates where observations are available, but did not show a statistically significant result (grey is below the statistically significant level for the modeled results).

flux response to dust is surprisingly similar to the residual unexplained carbon fluxes deduced from atmospheric concentrations, land and ocean biogeochemistry models in a recent synthesis (LeQuere et al., 2009) (Fig. 3e). This temporal covariance between the residual carbon flux and the flux associated with desert dust suggests that much of residual carbon flux may be associated with desert dust fluctuations. The model results suggest that as the land system moves from the relatively less dusty 1955-1964 period into the more dusty 1980-1989, there is a positive carbon flux from the land to the atmosphere. However, caution should be used in interpreting this comparison, since the precipitation shifts associated with the desert dust should already be included in the data used to drive the land biogeochemistry models used to derive the residual carbon flux.

Much of the change in terrestrial carbon occurs in the Northern Tropics $\left(0-20^{\circ} \mathrm{N}\right)$ in the model (Fig. 8a). The spatial distribution of the land carbon anomalies suggests that dust direct radiative forcing reduces productivity over large regions of the globe (Fig. 9a). Most of this reduction appears to be associated with changes in moisture availability (Fig. 9b), consistent with the shifts in precipitation predicted by the model (Fig. 6). This suggests that the shifts in precipitation are most important to these changes in land carbon uptake, not changes in insolation (direct vs. diffuse) (Mercado et al., 2009), but the sensitivity of the carbon uptake in this model to different forcings has not been tested rigorously.

\section{Uncertainty analysis}

We estimate the uncertainty from each part of the analysis in this paper. We use a simple approach in this first estimate of dust variability and impacts on the 20th century and add the uncertainty from each step in the process. First, to deduce the uncertainty associated with the estimated temporal 

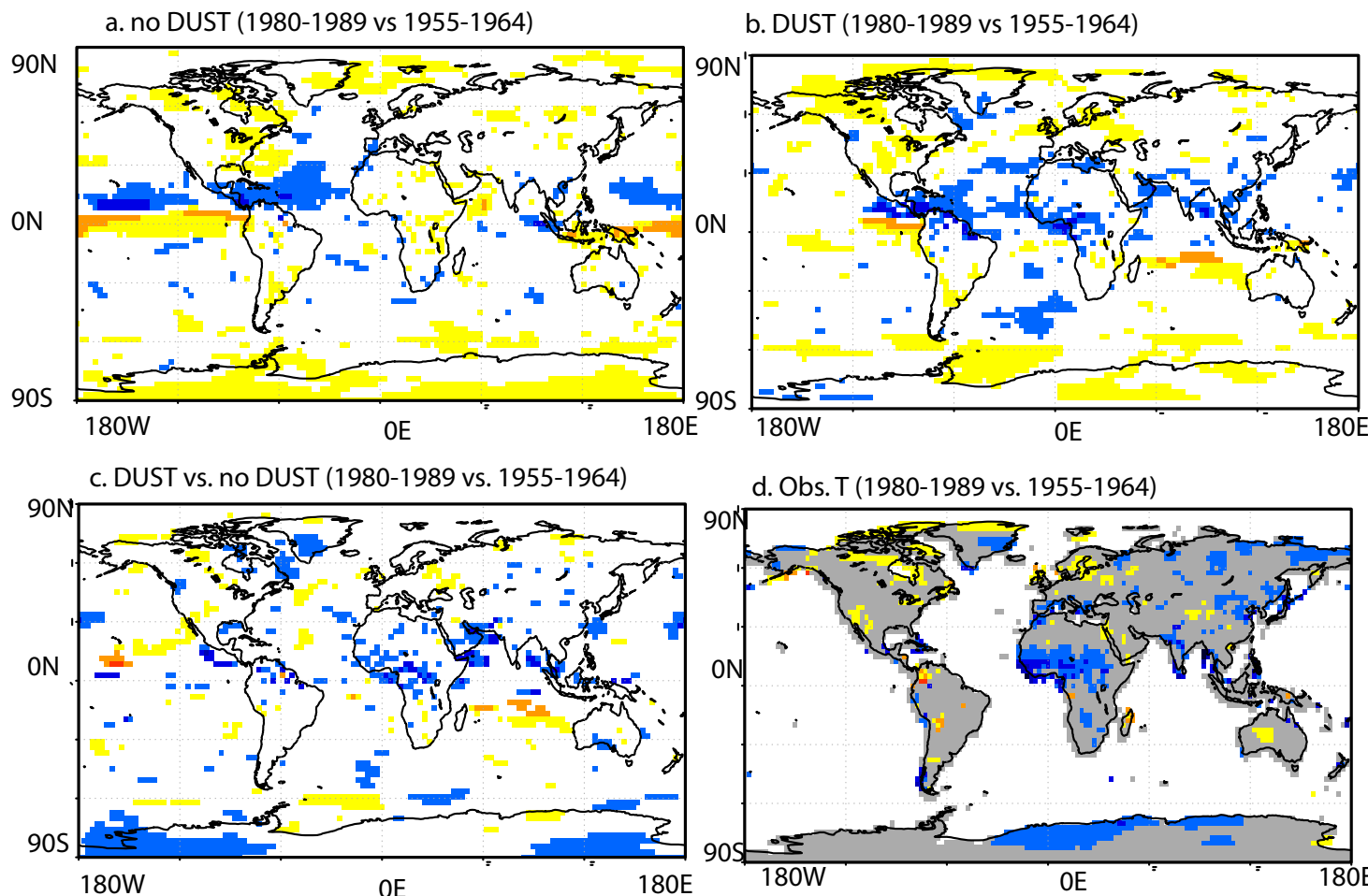

d. Obs. T (1980-1989 vs. 1955-1964)
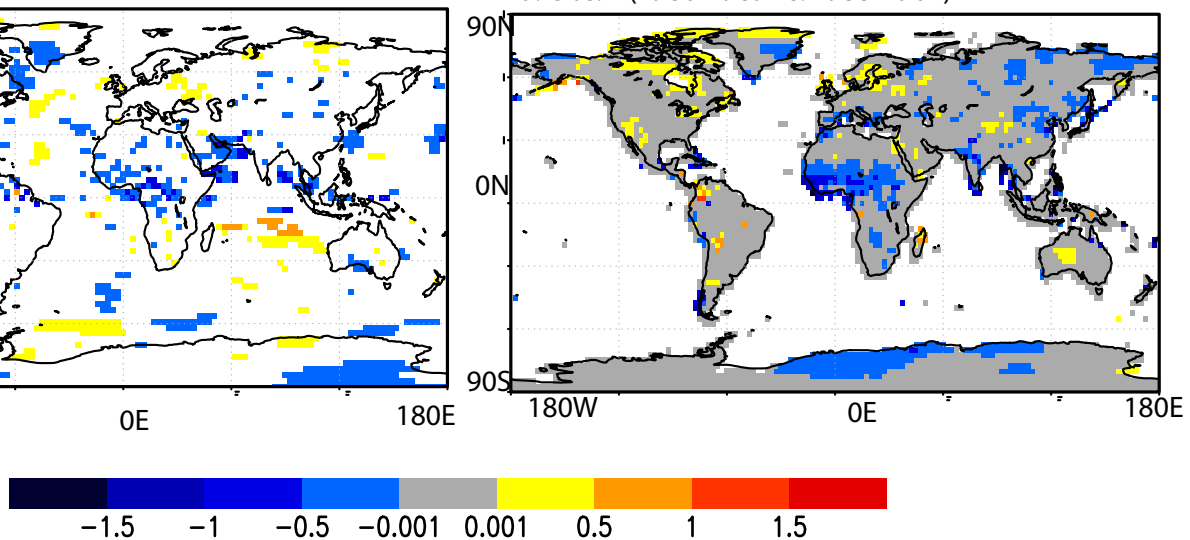

Fig. 6. Model estimated change in precipitation for 1980-1989 vs. 1955-1965 with no dust radiative forcing (a), with dust radiative forcing (b), and the difference in the precipitation change (1980-1989 minus 1955-1965) between simulations with and without dust radiative forcing (c). The change in precipitation between 1980-1989 vs. 1955-1965 from observations (only over land) (d). For (a-c) only statistically significant results at the $95 \%$ confidence level are shown, including all the ensemble members. For (d) the grey color indicates where observations are available, but did not show a statistically significant result (grey is below the statistically significant level for the modeled results).

variability in dustiness, we look at the variability in relative deposition across the deposition sites that we assume represent the same source. This uncertainty is estimated for the sources with the most paleodata records (Australia, South America and the Middle East/Central Asia) by calculating the standard deviation in relative deposition at each time, and then averaging this value over all times. This results in standard deviations in relative deposition of $41 \%, 28 \%$ and $33 \%$ for Australia, South America and the Middle East/Central Asia, respectively. We assume that the true uncertainty in our time series of source variability (due to the lack of sufficient paleodatasets) is the highest of these (40\%) for all our source regions for all time.

For the radiative forcing calculation and the climate response estimates in the model, there is additional uncertainty associated with the uncertainties in the optical properties of mineral aerosols. Based on the modeling studies included in the Intergovernmental Panel on Climate Change (IPCC), fo- cusing on those studies using single scattering albedos that match recent observations (Forster et al., 2007), we estimate approximately $20 \%$ uncertainty in the direct radiative forcing of dust. The climate response of the system to this radiative forcing appears to be to move precipitation away from the dust layer and cool surface temperatures in several model studies using observed single scattering albedo (Yoshioka et al., 2007). We thus assume that direct radiative forcing and climate responses to dust have an uncertainty of $40 \%$ (from source strength) plus $20 \%$ (from mineral aerosol optical property uncertainties), totaling $60 \%$.

The uncertainties in the indirect radiative forcing of the mineral aerosols are assumed to be the uncertainties associated with the dust variability, as well as the uncertainties associated with the indirect effect itself $(+100 \% /-50 \%)$ (Forster et al., 2007). In addition, we have not directly calculated the indirect effect, but rather estimated it based on anthropogenic aerosol results. We assume that the sign of 
Sea level pressure $(\mathrm{Pa})$
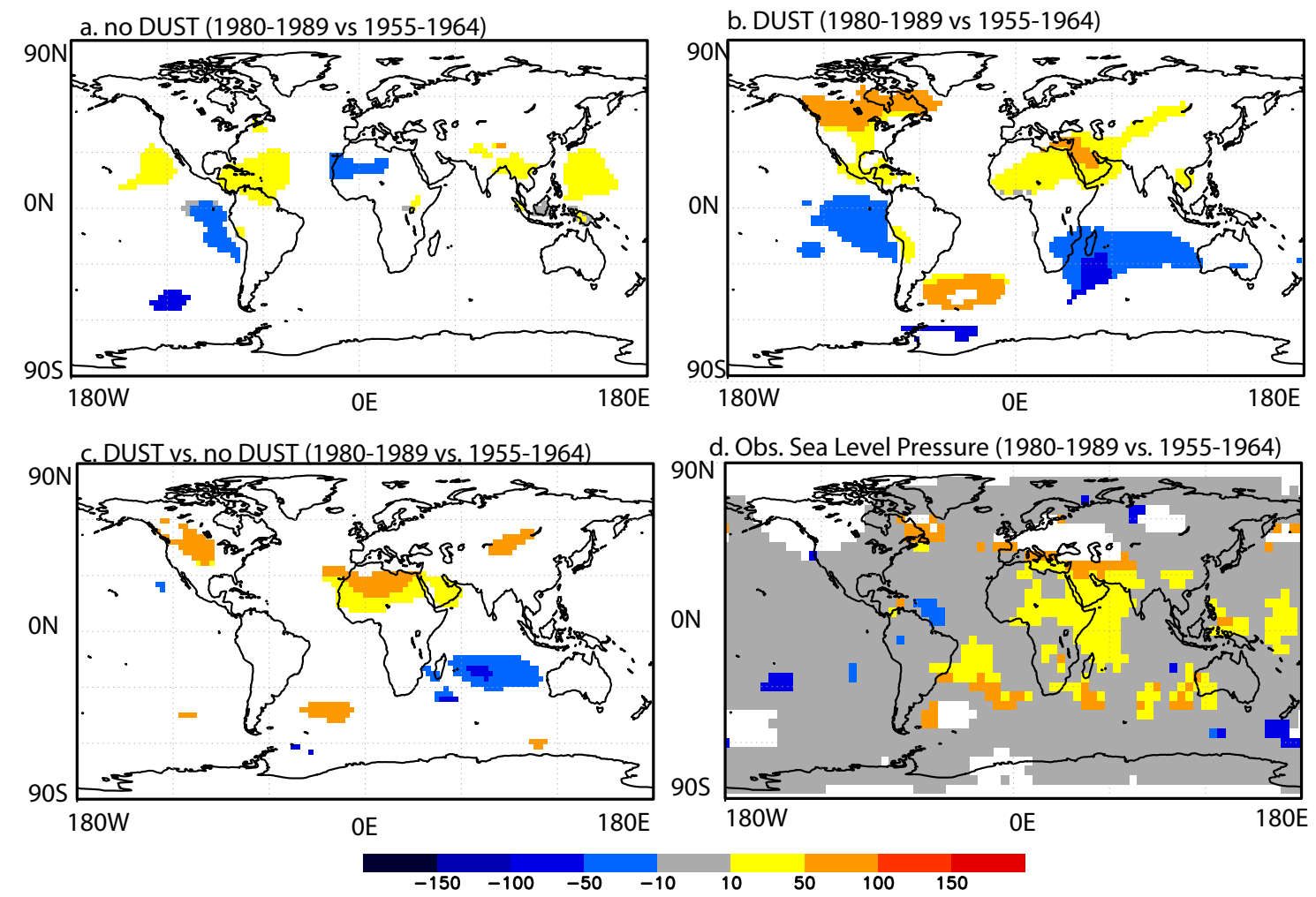

Fig. 7. Model estimated change in sea level pressure for 1980-1989 vs. 1955-1965 with no dust radiative forcing (a), with dust radiative forcing (b), and the difference in the sea level pressure change (1980-1989 minus 1955-1965) between simulations with and without dust radiative forcing (c). The change in sea level pressure between 1980-1989 vs. 1955-1965 from observationally based estimates (d). For (a-c) only statistically significant results at the $95 \%$ confidence level are shown, including all the ensemble members. For (d) the grey color indicates where observations are available, but did not show a statistically significant result (grey is below the statistically significant level for the modeled results).

the indirect effect is known (negative) so that we assume our uncertainties are $( \pm 100 \%)$.

Uncertainties in the response to dust in the ocean uptake of carbon dioxide are estimated using the ocean carbon response for several models included in a recent intercomparison (LeQuere et al., 2009), using the same dust forcing (Maltrud et al., 2010). The modeled response to iron was highly variable with uncertainties between $50-100 \%$. We assume here an uncertainty of $60 \%$, so that our total uncertainty in ocean response is $100 \%(40 \%+60 \%)$. The ocean modeling does not include any physical climate impacts of aerosols onto the ocean biogeochemistry, and thus the uncertainty estimate may be an underestimate.

For the land uptake of carbon, the uncertainties come from the dust variability (40\%), the radiative forcing and climate response (20\%), and uncertainties in different land model responses to the same forcing. We use a study that looked at the climate response for several carbon cycle models over 1958 to 2002. Over these five models (all of which were carbon- only models), the mean uptake is $83.2 \mathrm{PgC}$, with a standard deviation of $16.6 \mathrm{PgC}$, or $20 \%$ different (Sitch et al., 2008). We thus assume our uncertainty in land model uptake of carbon from dust is $80 \%(40 \%+20 \%+20 \%)$.

Notice that our uncertainties are large, and that much of the uncertainties are associated with the change in dustiness deduced from a relatively few paleodata sets. We include these uncertainty estimates into our radiative forcing calculations in Fig. 2.

\section{Summary and conclusions}

This study represents a first attempt to reconstruct desert dust variability over the 20th century based on observational and model synthesis. Our results have large uncertainties: much of the uncertainties are due to the sparse data available for this time period, thus suggesting that more paleodata records covering the recent past would improve our understanding 


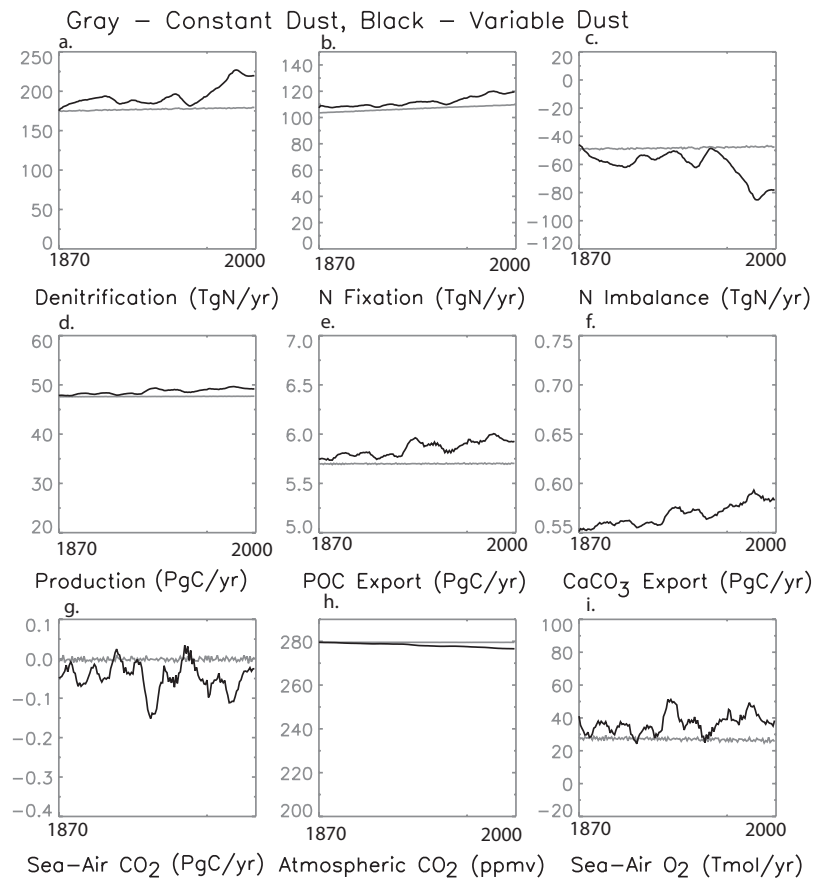

Fig. 8. Modeled ocean biogeochemical responses to desert dust changes for denitrification $(\mathbf{a})$, nitrogen $(\mathrm{N})$ fixation $(\mathbf{b})$, reactive nitrogen imbalance $(\mathbf{c})$, primary production $(\mathbf{d})$, particulate organic export (POC) (e), calcium carbonate export $\left(\mathrm{CaCO}_{3}\right)$ (f), sea-air carbon dioxide fluxes (f), atmospheric $\mathrm{CO}_{2}(\mathrm{~g})$, and sea-air oxygen fluxes (h).

of desert dust variability since the preindustrial time period. The North African, East Asian and Middle East/Central Asian sources are the most important, and least constrained, and thus should be the high priority for future observations. Using established models, we estimate the climate and biogeochemical response from these changes in 20th century dust. There remain large uncertainties in the response to desert dust in the models, due to uncertainties in desert dust distributions, optical parameters, and indirect effects in the atmosphere, as well as uncertainties in the ocean and land biogeochemistry models and their responses to desert dust.

We do not consider important interactions such as the impact of desert dust aerosols on air quality and health (Prospero, 1999), and atmospheric chemistry (Dentener et al., 1996). We deal with the potential for indirect effect of aerosols on climate with a simple, back of the envelope approach, and do not consider the complete effects of indirect forcing as in a full, interactive model. In addition, the changes in desert dust reconstructed here will impact the indirect effects of anthropogenic aerosols by providing additional surfaces for condensation to occur on.

Our results suggest that desert dust roughly doubled over the 20th century over much, but not all the globe (Fig. 3a and b). The largest estimated differences were between the dusty 1980-1989 period compared to the relatively dust-free 1955-
Total Column Carbon (gC/m2)

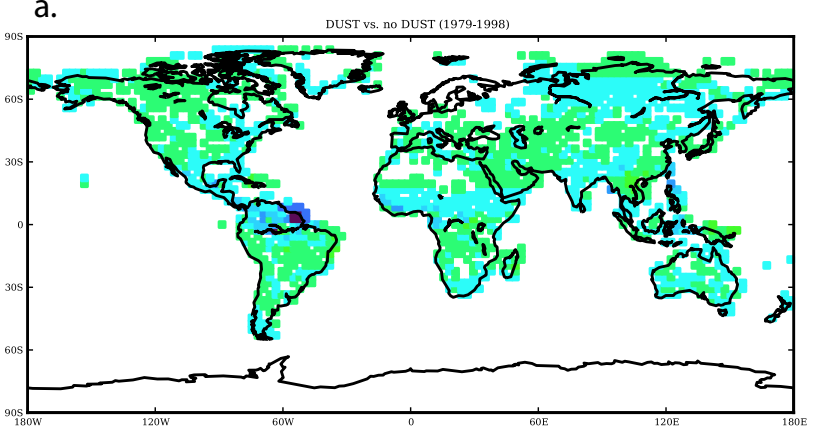

$\begin{array}{ccccccc}-5.4 \mathrm{e}+03 & -3.6 \mathrm{e}+03 & -1.8 \mathrm{e}+03 & 0.0 \mathrm{e}+00 & 1.8 \mathrm{e}+03 & 3.6 \mathrm{e}+03 & 5.4 \mathrm{e}+03\end{array}$
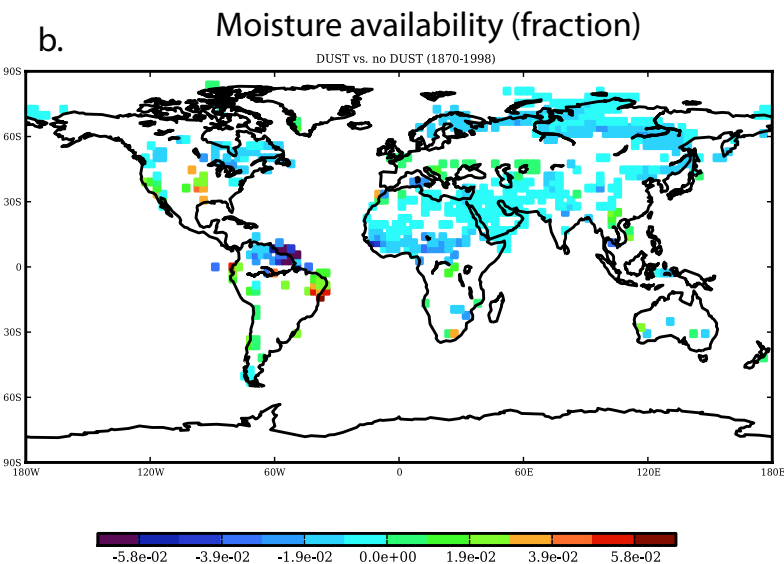

Fig. 9. The change in total land column carbon inventory because of dust variations and their impact on radiative (averaged over 19791998) (a), and the change in moisture availability for growth (averaged over 1870-1998) due to dust (simulations including dust radiative forcing minus simulations not including dust radiative forcing. An increase in the latter value indicates that the plants have more moisture available to them for growth.

1964 period. The net radiative forcing due to dust between the dusty (1980-1989) and non-dusty (1955-1964) time periods is $-0.57 \mathrm{~W} / \mathrm{m}^{2} \pm 0.46$ (Fig. 4a). A smaller net radiative forcing for the change in dust of $-0.14 \pm 0.11 \mathrm{~W} / \mathrm{m}^{2}$ is obtained for the time period of 1990-1999 compared with 1905-1914 from the direct radiative forcing, indirect radiative forcing of the aerosols, as well as the impact of carbon uptake and release by the ocean and land ecosystems. Including desert dust fluctuations in climate model simulations improves our ability to simulate decadal scale variability in global surface temperature (Fig. 3c), regional changes in temperature and precipitation (Fig. $4 \mathrm{~b}$ and c), and possibly explains the residual global carbon flux unexplained by other mechanisms (LeQuere et al., 2009) (Fig. 3e). Thus, continued work to refine the variability and impact of "natural" desert dust fluctuations over the 20th century is important. 
Acknowledgements. We would like to acknowledge NASA grants NNG06G127G and NNX07AL80G, NSF grants NSF-0832782, 0932946, 0745961 and OPP-0538427, and the UK Natural Environment Research Council. These simulations were conducted at the National Center for Atmospheric Research, a National Science Foundation funded facility. Comments by Ron Miller improved the manuscript. We would like to thank three anonymous reviewers for their helpful comments.

Edited by: C. McNeil

\section{References}

Allan, R. J. and Ansell, T. J.: A new globally complete monthly historical mean sea level pressure data set (HadSLP2): 18502004, J. Climate, 19, 5816-5842, 2006.

Andersen, K. K., Armengaud, A., and Genthon, C.: Atmospheric dust under glacial and interglacial conditions, Geophys. Res. Lett., 25, 2281-2284, 1998.

Aumont, O., Bopp, L., and Schulz, M.: What does temporal variability in aeolian dust deposition contribute to sea-surface iron and chlorophyll distributions?, Geophys. Res. Lett., 35, L07607, doi:10.1029/2007GL031131, 2008.

Bonan, G., Levis, S., Kergoat, L., and Oleson, K.: Landscapes as patches of plant functional types: An integrating concept for climate and ecosystem models, Global Biogeochem. Cy., 16, 5.15.23, 2002.

Bonfils, C., Noblet-ducoudre, N. D., Braconnot, P., and Joussaume, S.: Hot desert albedo and climate change: mid-holocene monsoon in North Africa, J. Climate, 14, 3724-3737, 2001

Boyd, P. W. and Law, C. S.: The Southern Ocean Iron Release Experiment (SOIREE) introduction and summary, Deep-Sea Res. II, 48, 2425-2438, 2001.

Brohan, P., Kennedy, J., Harris, I., Tett, S., and Jones, P.: Uncertainty estimates in regional and global observed temperature changes: a new dataset from 1850, J. Geophys. Res., 111, D12106, doi:10.1029/2005JD006548, 2006.

Collins, W., Bitz, C., Blackmon, M., Bonan, G., Bretherton, C., Carton, J., Chang, P., Doney, S., Hack, J., Henderson, T., Kiehl, J., Large, W., McKenna, D., Santer, B., and Smith, R.: The community climate system model: CCSM3, J. Climate, 19, 21222143, 2006a.

Collins, W. D., Rasch, P. J., Boville, B. A., Hack, J. J., McCaa, J. R., L.Williamson, D., Briegleb, B. P., Bitz, C. M., Lin, S.-J., and Zhang, M.: The formulation and atmospheric simulation of the Community Atmosphere Model, CAM3, J. Climate, 19, 21442161, 2006b.

Dai, A., Trenberth, K., and Qian, T.: A global dataset of Palmer Drought Severity Index for 1870-2002: Relationship with soil moisture and the effects of surface warming, J. Hydrometeorol., 5, 1117-1130, 2004.

Delmonte, B., Petit, J. R., Basile-Doelsch, I., Jagoutz, E., and Maggi, V.: Late Quaternary Interglacials in East Antarctica From Ice-Core Dust Records, The Climate of Past Interglacials, edited by: Sirocko, F., Litt, T., and Clausen, M., Elsevier, Amsterdam, 53-73, 2007.

Delmonte, B., Delmas, R. J., and Petit, J.-R.: Comment on "Dust provenance in Antarctic ice during glacial periods: from where in southern South America?", Geophys. Res. Lett., 35, L08707, doi:10.1029/2007GL032075(032008), 2008.

DeMott, P., Sassen, K., Poellot, M., Baumgardner, D., Rogers, D., Brooks, S., Prenni, A., and Kreidenweis, S.: African dust aerosols as atmospheric ice nuclei, Geophys. Res. Lett., 30, 1732, doi:1710.1029/2003GL017410, 2003.

Dentener, F. J., Carmichael, G. R., Zhang, Y., Lelieveld, J., and Crutzen, P. J.: Role of mineral aerosol as a reactive surface in the global troposphere, J. Geophys. Res., 101, 22869-22889, 1996.

Donarummo, J., Ram, M., and Stolz, M. R.: Sun/dust correlations and volcanic interference, Geophys. Res. Lett., 29(9), 1361, doi:10.1029/2002g1014858, 2002.

Doney, S., Lima, I., Moore, J. K., Behrenfeld, M., mahowald, N., Maltrud, M., Glober, D., McGillicuddy, D., and Takahashi, T.: Skill metrics for confronting global upper ocean ecosystem biogeochemistry models against field and remote sensing data, J. Mar. Sci., 76, 95-112, 2009.

Falkowski, P. G., Barber, R. T., and Smetacek, V.: Biogeochemical Controls and Feedbacks on Ocean Primary Production, Science, 281, 200-206, 1998.

Flanner, M. and Zender, C.: Linking snowpack microphysics and albedo evolution, J. Geophys. Res., 111, D12208, doi:10.1029/.2005JD006834, 2006.

Flanner, M. G., Zender, C. S., Randerson, J. T., and Rasch, P. J.: Present-Day Climate Forcing and Response from Black Carbon in Snow, J. Geophys. Res., 112(D11), D11202, doi:10.1029/2006JD008003, 2007.

Flanner, M. G., Zender, C. S., Hess, P. G., Mahowald, N. M., Painter, T. H., Ramanathan, V., and Rasch, P. J.: Springtime warming and reduced snow cover from carbonaceous particles, Atmos. Chem. Phys., 9, 2481-2497, doi:10.5194/acp-9-24812009, 2009.

Forster, P., Ramaswamy, V., Artaxo, P., Berntsen, T., Betts, R., Fahey, D. W., Haywood, J., Lean, J., Lowe, D. C., Myhre, G., Nganga, J., Prinn, R., Raga, G., Schulz, M., and Van Dorland, R.: Changes in Atmospheric Constituents and in Radiative Forcing, in: Climate Change 2007: The Physical Science Basis. Contribution of Working Group I to the Fourth Assessment Report of the Intergovernmental Panel on Climate Change, edited by: Solomon, S., Qin, D., Manning, M., Chen, Z., Marquis, M., Averyt, K. B., Tignor, M., and Miller, H. L., Cambridge University Press, Cambridge, United Kingdom and New York, NY, USA, 130-234, 2007.

Fung, I., Meyn, S. K., Tegen, I., Doney, S., John, J., and Bishop, J.: Iron supply and demand in the upper ocean, Global Biogeochem. Cy., 14, 281-295, 2000.

Gaiero, D. M.: Reply to comment by B. Delmonte et al. on "Dust provenance in Antarctic ice during glacial periods: From where in southern South America?", Geophys. Res. Lett., 35, L08708, doi:10.1029/2007GL032477(032008), 2008.

Gillette, D. A.: Threshold friction velocities for dust production for agricultural soils, J. Geophys. Res., 93, 12645-12662, 1988.

Gillette, D., Hardebeck, E., and Parker, J.: Large-scale variability of wind erosion mass flux rates at Owens Lake2. Role of roughness change, particle limitation, change of threshold friction velocity, ant the Owen effect, J. Geophys. Res., 102, 25989-25998, 1997.

Ginoux, P., Chin, M., Tegen, I., Prospero, J. M., Holben, B. N., Dubovik, O., and Lin, S.-J.: Sources and distribution of dust aerosols with the GOCART model, J. Geophys. Res., 106, 
20255-20273, 2001

Grousset, F. and Biscaye, P.: Tracing dust sources and transport patterns using $\mathrm{Sr}$, $\mathrm{Nd}$ and $\mathrm{Pb}$ isotopes, Chem. Geol., 222, 149$167,2005$.

Hoose, C., Lohmann, U., Erdin, R., and Tegen, I.: Global Influence of Dust Mineralogical Composition on Heterogeneous Ice Nucleation in Mixed-Phase Clouds, Environ. Res. Lett., 3, 025003, doi:10.1088/1748-9326/3/2/025003, 2008.

Jones, C., Lowe, J., Liddicoat, S., and Betts, R.: Committed terrestrial ecosystem changes due to climate change, Nature Geosci., 2(7), doi:10.1038/ngeo1555, 2009.

Kaspari, S., Mayewski, P., Kang, S., Sneed, S., Hou, S., Hooke, R., Kreutz, K., Introne, D., Handley, M., Maasch, K., Qin, D., and Ren, J.: Reduction in northward incursions of the South Asian monsson since $\sim 1400$ AD inferred from a Mt. Everest ice core, Geophys. Res. Lett., 34, L16701, doi:10.1029/2007GL030440, 2007.

Kohfeld, K. E. and Harrison, S. P.: DIRTMAP: the geological record of dust, Earth Sci. Rev., 54, 81-114, 2001.

Koretsky, C., Sverjensky, D., Salisbury, J., and D'Aria, D.: Detection of surface hydroxyl speies on quart, gamma-alumina and feldspars using diffuse reflectance infrared spectroscopy, Geochim. Cosmochim. Acta, 61, 2193-2210, 1997.

Krishnamurty, A., Moore, J. K., Mahowald, N., Luo, C., Doney, S., Lindsay, K., and Zender, C.: Impacts of increasing anthropogenic soluble iron and nitrogen deposition on ocean biogeochemistry, Global Biogeochem. Cy., 23, BG3016, doi:10.1029/2008/GB003440, 2009.

LeQuere, C., Raupach, M., Canadell, J., Marland, G., Bopp, L., Ciasa, P., Conway, T., Doney, S., Feely, R., Foster, P., Friedlingstein, P., Gurney, K., Hougton, R., House, J., Hungtingford, C., Levy, P., Lomas, M., Majkut, J., Metzl, N., Ometto, J., Peters, G., Prentice, I. C., Randerson, J., Running, S., Sarmiento, J., Schuter, U., Sitch, S., Takahashi, T., Viovy, N., Werf, G. v. d., and Woodward, F.: Trends in the sources and sinks of carbon dioxide, Nature Geosci., 2, 1831-1836, doi:10.1038/ngeo1689, 2009.

Li, F., Ginoux, P., and Ramaswamy, V.: Distribution, transport and depositoin of mineral dust in the Southern Ocean and Antarctica: Contributions of major sources, J. Geophys. Res., 113, D10207, doi:10.1029/2007JD009190, 2008.

Luo, C., Mahowald, N., and Corral, J.: Sensitivity study of meteorological parameters on mineral aerosol mobilization, transport and idstribution, J. Geophys. Res., 108, 4447, 4410.1029/2003JD0003483, 2003.

Mahowald, N.: Anthropocence changes in desert are: sensitivity to climate model predictions, Geophys. Res. Lett., 34, 1475, doi:10.1029/2007GL030472, 2007.

Mahowald, N. and Kiehl, L.: Mineral aerosol and cloud interactiocns, Geophys. Res. Lett., 30, 1475, doi:10.109/2002GL016762, 2003.

Mahowald, N. M. and Luo, C.: A less dusty future?, Geophys. Res. Lett., 30, 1903, doi:1910.1029/2003GRL017880, 2003.

Mahowald, N., Kohfeld, K., Hansson, M., Balkanski, Y., Harrison, S. P., Prentice, I. C., Shulz, M., and Rodhe, H.: Dust sources and deposition during the last glacial maximum and current climate: A comparison of model results with paleodata from ice cores and marine sediments, J. Geophys. Res., 104, 15895-15916, 1999.

Mahowald, N., Zender, C., Luo, C., Corral, J., Savoie, D., and Tor- res, O.: Understanding the 30-year Barbados desert dust record, J. Geophys. Res., 107, 4561, doi:10.129/2002JD002097, 2002.

Mahowald, N., Luo, C., Corral, J. d., and Zender, C.: Interannual variability in atmospheric mineral aerosols from a 22-year model simulation and observational data, J. Geophys. Res., 108, 4352, doi:4310.1029/2002JD002821, 2003.

Mahowald, N., Rivera, G., and Luo, C.: Comment on "Relative importance of climate and land use in determining present and future global soil dust emission", Geophys. Res. Lett., 31, L24105, doi:24110.21029/22004GL021272, 2004.

Mahowald, N., D. Muhs, Levis, S., Rasch, P., Yoshioka, M., and Zender, C.: Change in atmospheric mineral aerosols in response to climate: last glacial period, pre-industrial, modern and doubled-carbon dioxide climates, J. Geophys. Res., 111, D10202, doi:10210.11029/12005JD006653, 2006a.

Mahowald, N., Yoshioka, M., Collins, W., Conley, A., Fillmore, D., and Coleman, D.: Climate response and radiative forcing from mineral aerosols during the last glacial maximum, pre-industrial and doubled-carbon dioxide climates, Geophys. Res. Lett., 33, D10202, doi:10.1029/2006GL026126, 2006b.

Mahowald, N., Engelstaedter, S., Luo, C., Sealy, A., Artaxo, P., Benitez-Nelson, C., Bonnet, S., Chen, Y., Chuang, P. Y., Cohen, D. D., Dulac, F., Herut, B., Johansen, A. M., Kubilay, N., Losno, R., Maenhaut, W., Paytan, A., Prospero, J. M., Shank, L. M., and Siefert, R. L.: Atmospheric Iron deposition: Global distribution, variability and human perturbations, Annu. Rev. Mar. Sci., 1, 245-278, doi:210.1146/annurev/marine.010908.163727, 2009.

Mahowald, N., Albani, S., Engelstaedter, S., Winckler, G., and Goman, M.: Model insight into paleodust records, Quarternary Sci. Rev., accepted, 2010.

Maltrud, M., Chavez, F. P., Dutkiewicz, S., Gruber, N., Jin, X., Sarmiento, J. L., Tagliabue, A., Doney, S., and Lima, I.: Atmospheric cabon dioxide reduction from ocean iron fertilization: a model intercomparison study, in preparation, 2010.

Marino, F., Castellano, E., Ceccato, D., Deckker, P. D., Delmonte, B., Ghermandi, G., Maggi, V., Petit, J. R., RevelRolland, M., and Udisti, R.: Defining the geochemical composition of the EPICA Dome $\mathrm{C}$ ice core during the last glacial-interglacial cycle, Geochem. Geophy. Geosy., 9, 002008, doi:10.1029/2008GC002023(002008), 2008.

Martin, J., Gordon, R. M., and Fitzwater, S. E.: The case for iron, Limnol. Oceanogr., 36, 1793-1802, 1991.

Mayewski, P. A., Lyons, W. B., Zielinski, G., Twickler, M., Whitlow, S., Dibb, J., Grootes, P., Tay- lor, K., Whung, P. Y., Fosberry, L., Wake, C., and Welch, K.: An ice-core based late Holocene history for the Transantarctic mountains, Antarctica, Contributions to Antarctic Research IV, Antarctic Res. Series, 67, 33-45, 1995.

McConnell, J. and Edwards, R.: Coal burning leaves toxic metal legacy in the Arctic, P. Natl. Acad. Sci., 105(34), doi:10.1073/pnas.083564105, 2008.

McConnell, J. R., Aristarain, A., Banta, J., Edwards, P., and Simoes, J.: 20th Century doubling in dust archived in an Antarctic Penisula ice core parallels climate change and desertification in South America, P. Natl. Acad. Sci., 104, 5743-5748, 2007.

Meeker, L. and Mayewski, P.: 1400-year high resolution record of atmospheric circulation over the North Atlantic and Asia, The Holocene, 12, 257-266, 2002. 
Mercado, L., Bellouin, N., Stich, S., Boucher, O., Huntingford, C., Wild, M., and Wild, P.: Impacts of changes in diffuse radiation on the global land carbon sink, Nature, 458, 01014-01018, doi:10.1028/nature07949, 2009.

Miller, R. and Tegen, I.: Climate Response to Soil Dust Aerosols, American Meteorlogical Society, 11, 3247-3267, 1998.

Moore, C. M., Mills, M., Milnes, A., Langois, R., Achterberg, E., Lochte, K., Geider, R., and LaRoche, J.: iron limits primary productivity during spring blooms development in the central North Atlantic, Glob. Change Biol., 12, 626-634, 2006.

Mosley-Thompson, E., Thompson, L. G., Grootes, P., and Gundestrup, N.: Little ice age (neoglacial) paleoenvironmental conditions at siple station, Antarctica, J. Glaciol., 14, 199-204, 1990.

Moullin, C. and Chiapello, I.: Impact of human-induced desertification on the intensification of the Sahel dust emission and export over the last decades, Geophys. Res. Lett., 33, L18808, doi:10.1029/2006GL025923, 2006.

Mukhopadhyay, S. and Kreycik, P.: Dust generation and drought patterns in Africa from helium-4 in a modern Cape Verde coral, Geophys. Res. Lett., 35, L20820, doi:10.1029/2008GL035722, 2008.

Mulitza, S., Heslop, D., Pittauerova, D., Fischer, H., Meyer, I., Stuut, J.-B., Zabel, M., Mollenhauer, G., Collins, J., Kuhnert, H., and Schulz, M.: Increase in African dust flux at the onset of commercial agriculture in the Sahel region, Nature, 466, 0922609228, doi:10.1038/nature09213, 2010.

Neff, J., Reynolds, R., Belnap, J., and Lamothe, P.: Multi-decadal impacts of grazing on soil physical and biogeochemical properties in southeast Utah, Ecol. Appl., 15, 87-95, 2005.

Neff, J. C., Ballantyne, A. P., Farmer, G. L., Mahowald, N., Conroy, J. L., Landry, C. C., Overpeck, J. T., Painter, T. H., Lawrence, C. R., and Reynolds, R. L.: Increasing eolian dust deposition in the western United States linked to human activity, Nature Geosci., 1(3), doi:10.1038/ngeo, 2008.

Okin, G., Mahowald, N., Chadwick, O., and Artaxo, P.: The impact of desert dust on the biogeochemistry of phosphorus in terrestrial ecosystems, Global Biogeochem. Cy., 18, GB2005, doi:2010.1029/2003GB002145, 2004.

Oleson, K. W., Niu, G.-Y., Yang, Z.-L., Lawrence, D. M., Thornton, P. E., Lawrence, P. J., Stockli, R., Dickinson, R. E., Bonan, G. B., Levis, S., Dai, A., and Qian, T.: Improvements to the Community Land Model and their impact on the hydrological cycle, J. Geophys. Res., 113, G01021, doi:10.1029/2007JG000563, 2008.

Parekh, P., Dutkiewicz, S., Follows, M., and Ito, T.: Atmospheric carbon dioxide in a less dusty world, Geophys. Res. Lett., 33, L03610, doi:10.1029/2005GL025098, 2006.

Patterson, D., Farley, K., and Norman, M.: He-4 as a tracer of continental dust: A 1.9 million year record of aeolian flux to the west equatorial Pacific Ocean, Geochem. Geophy. Geosy., 63, 615$625,1999$.

Perlwitz, J., Tegen, I., and Miller, R.: Interactive soil dust aerosol model in the GISS GCM 1. Sensitivity of the soil dust cycle to radiative properties of soil dust aerosols, J. Geophys. Res., 106, 18167-18192, 2001.

Petit, J. R., Jouzel, J., Raynaud, D., Barkov, N. I., Barnola, J.-M., Basile, I., Bender, M., Chappellaz, J., Davis, M., Delaygue, G., Delmotte, M., Kotlyakov, V. M., Legrand, M., Lipenkov, V. Y., Lorius, C., Pepin, L., Ritz, C., Saltzman, E., and Stievenard, M.: Climate and atmospheric history of hte past 420000 years from the Vostok Ice core, Antarctica, Nature, 399, 429-436, 1999.

Prospero, J. M.: Long-range transport of mineral dust in the global atmosphere: Impact of African dust on the environment of the southeastern United States, P. Natl. Acad. Sci., 96, 3396-3403, 1999.

Prospero, J. and Lamb, P.: African droughts and dust transport to the Caribbean: climate change implications, Science, 302, 1024 $1027,2003$.

Prospero, J., Ginoux, P., Torres, O., Nicholson, S., and Gill, T.: Environmental Characterization of Global sources of atmospheric soil dust derived from the NIMBUS-7 TOMS absorbing aerosol product, Rev. Geophys., 40, 1002, doi:1010.1029/2000RG000095, 2002.

Reheis, M. C.: Dust deposition downwind of Owens (dry) Lake, 1991-1994: Preliminary findings, J. Geophys. Res., 102, 25999 26008, 1997.

Rosenfeld, D. and Nirel, R.: Seeding effectiveness-the interaction of desert dust and the southern margins of rain cloud systems in Israel, J. Appl. Meteorol., 35, 1502-1509, 1996.

Rosenfeld, D., Rudich, Y., and Lahav, R.: Desert dust suppressing precipitation: a possible desertification feedback loop, P. Natl. Acad. Sci. USA, 98, 5975-5980, 2001.

Rosenfeld, D., Lohmann, U., Raga, G., O’Dowd, C., Kulmala, M., Fuzzi, S., Reissell, A., and Andreae, M.: Flood or drought: how do aerosols affect precipitation?, Science, 321, 1309-1312, doi:1310.1126/science.1160606, 2008.

Sassen, K.: Indirect climate forcing over the western US from Asian dust storms, Geophys. Res. Lett., 29, 012002, doi:10.1029/2001GL014051, 2002.

Sitch, S., Huntingford, C., Gedney, N., Levy, P., Lomas, M., Piao, S. L., Betts, R., Cias, P., Cox, P., Friedlingstein, P., Jones, C. D., Prentice, I. C., and Woodward, F. I.: Evaluation of terrestrial carbon cycle, future plant geography and climate-carbon cycle feedbacks using five dynamic global vegetation models (DGVMs), Glob. Change Biol., 14, 2015-2039, doi:2010.1111/j.1365-2486.2008.01626.x, 2008.

Smith, S., Huxman, T., Zitzer, S., Charlet, T., Housman, D., Coleman, J., Fenstermaker, L., Seemann, J., and Nowak, R.: Elevated $\mathrm{CO}_{2}$ increases productivity and invasive species success in an arid ecosystem, Nature, 408, 79-82, 2000.

Souney, J. M., Mayewski, P. A., Godwin, I., Morgan, V., Curran, M. A. J., van Ommen, T. D., and Palmer, A. S.: A late Holocene climate record from Law Dome, East Antarctica, J. Geophys. Res., 107, 1-9, 2002.

Swap, R., Garstang, M., Greco, S., Talbot, R., and Kallberg, P.: Saharan dust in the Amazon Basin, Tellus, 44B, 133-149, 1992.

Tegen, I. and Fung, I.: Contribution to the atmospheric mineral aerosol load from land surface modification, J. Geophys. Res., 100, 18707-18726, 1995.

Tegen, I. and Miller, R.: A general circulation model study on the interannual variability of soil dust aerosol, J. Geophys. Res., 103, 25975-25,995, 1998.

Tegen, I., Werner, M., Harrison, S. P., and Kohfeld, K. E.: Relative importance of climate and land use in determining present and future global soil dust emission, Geophys. Res. Lett., 31, L05105, doi:05110.01029/02003GL019216, 2004.

Thompson, L. G., Mosley-Thompson, E., Grootes, P., and Pourchet, M.: Tropical glaciers: potential for paleoclimatic reconstruction, J. Geophys. Res., 89, 4638-4646, 1984. 
Thompson, L. G., Mosley-Thompson, E., Davis, M. E., Lin, P.N., Henderson, K. A., Cole-Dai, J., Bolzan, J. F., and Liu, K.-B.: Late Glacial Stage and Holocene Tropical Ice Core Records from Huascarán, Peru, Science, 269, 46-50, 1995.

Thompson, L. G., Yao, T., Mosley-Thomspon, E., Davis, M. E., Henderson, K. A., and Lin, P. N.: A High-Resolution Millennial Record of the South Asian Monsson from Himalayan Ice Cores, Science, 289, p. 5486, 2000.

Thompson, L. G., Mosley-Thompson, E., Davis, M., Henderson, K., Brecher, H. H., Zagaorodnov, V. S., Mashiotta, T. A., Lin, P.N., Mikhalenko, V. N., Hardy, D. R., and Beer, J.: Kilimanjaro ice core records: evidence of Holocene climate change in tropical africa, Science, 298, 589-593, 2002.

Thornton, P., Lamarque, J. F., Rosenbloom, N. A., and Mahowald, $\mathrm{N}$.: Influence of carbon-nitrogen cycle couplng on land model response to $\mathrm{CO}_{2}$ fertilization and climate variability, Global Biogeochem. Cy., 21, GB4018, doi:10.1029/2006GB002868, 2007.

Thornton, P. E., Doney, S. C., Lindsay, K., Moore, J. K., Mahowald, N., Randerson, J. T., Fung, I., Lamarque, J.-F., Feddema, J. J., and Lee, Y.-H.: Carbon-nitrogen interactions regulate climate-carbon cycle feedbacks: results from an atmosphereocean general circulation model, Biogeosciences, 6, 2099-2120, doi:10.5194/bg-6-2099-2009, 2009.

Vitousek, P.: Stoichiometry and flexibility in the Hawaiian model system, in: Interactions of the Major Biogeochemical cycles: Global Change and Human Impacts, edited by: Melillo, J., Field, C., and Moldan, B., Island Press, Washington, DC, 177-192, 2003.
Werner, M., Tegen, I., Harrison, S., Kohfeld, K., Prentice, I. C., Balkanski, Y., Rodhe, H., and Roelandt, C.: Seasonal and interannual variability of the mineral dust cycle under present and glacial climate conditions, J. Geophys. Res., 107, 4744, doi:4710.1029/2002JD002365, 2002.

Winckler, G., Anderson, R. F., and Schlosster, P.: Equatorial Pacific productivity and dust flux during the midPleistocene climate transition, Paleoceanography, 20, PA4025, doi:10.1029/2005PA001177, 2005.

Yoshioka, M., Mahowald, N., Dufresne, J.-L., and Luo, C.: Simulation of absorbing aerosol indices for African dust, J. Geophys. Res., 110, D18S17, doi:10.1029/2004JD005276, 2005.

Yoshioka, M., Mahowald, N., Conley, A., Collins, W., Fillmore, D., and Coleman, D.: Impact of desert dust radiative forcing on Sahel precipitation: relative importance of dust compared to sea surface temperature variations, vegetation changes and greenhouse gas warming, J. Climate, 20, 1445-1467, 2007.

Zdanowicz, C. M., Zielinski, G. A., and Wake, C. P.: Characteristics of modern atmospheric dust deposition in snow on the Penny ice cap, Baffin Island, Arctic Canada, Tellus, 50B, 506-520, 1998.

Zender, C., Bian, H., and Newman, D.: Mineral Dust Entrainment and Deposition (DEAD) model: Description and 1990s dust climatology, J. Geophys. Res., 108, 4416, doi:4410.1029/2002JD002775, 2003a.

Zender, C., Newman, D., and Torres, O.: Spatial Heterogeneity in Aerolian Erodibility: Uniform, Topographic, Geomorphic and Hydrologic Hypotheses, J. Geophys. Res., 108, 4543, doi:4510.1029/2002JD003039, 2003b. 